\title{
Show Me the Money: The Monetary Policy Risk Premium
}

\author{
Ali Ozdagli and Mihail Velikov
}

\begin{abstract}
:
We study how monetary policy affects the cross-section of expected stock returns. For this purpose, we create a parsimonious monetary policy exposure (MPE) index based on observable firm characteristics that are theoretically linked to how firms react to monetary policy. We find that stocks whose prices react more positively to expansionary monetary policy surprises earn lower average returns. This finding is consistent with the intuition that monetary policy is expansionary in bad economic times when the marginal value of wealth is high, and thus high MPE stocks serve as a hedge against bad times. A long-short trading strategy designed to exploit this effect achieves an annualized value-weighted return of 9.96 percent with an associated Sharpe Ratio of 0.93 between 1975 and 2015. This return premium cannot be explained by standard factor models and survives a battery of robustness tests.
\end{abstract}

Keywords: monetary policy, asset pricing, risk factors

JEL Classifications: E12, E31, E44, E52, G12, G14

Ali Ozdagli is an economist in the research department of the Federal Reserve Bank of Boston. Mihail Velikov is a. financial economist in the supervision, regulation, and credit department of the Federal Reserve Bank of Richmond. Their e-mail addresses are ali.ozdagli@bos.frb.org, and mihail.velikov@rich.frb.org, respectively.

This paper, which may be revised, is available on the web site of the Federal Reserve Bank of Boston at http://www.bos.frb.org/economic/wp/index.htm.

We thank Ravi Bansal, Bruno Biais, Nina Boyarchenko (FRS Macro Meeting discussant), Andrea Buraschi, Robin Greenwood, Lars Hansen, Gur Huberman, Marcin Kacperczyk, Emanuel Moench, Robert Novy-Marx, Jonathan Newell, Jonathan Parker, Joe Peek, Carolin Pflueger, Nick Roussanov, Eric Swanson, Jenny Tang, Pietro Veronesi, Michael Weber, and seminar participants at CEPR ESSFM, FRB Boston, FRS Committee on Macro Meeting, and Penn State for discussions and comments. All mistakes are ours alone.

The views expressed in this paper are those of the authors and do not necessarily represent the position of the Federal Reserve Bank of Boston, the Federal Reserve Bank of Richmond, or the Federal Reserve System.

This version: December 2016 
We expect a Fed tightening and are cautious about our exposures. Please understand that we are not sure of anything but...we do not want to have any concentrated bets.

Ray Dalio, Bridgewater, March 11, 2015

\section{Introduction}

Within the large strand of macroeconomics literature that studies monetary policy, a substantial subset examines the effects of monetary policy on asset prices. Because the most immediate effects of policy actions are felt in financial markets, understanding the differential responses in the cross-section of equities is crucial for our understanding of the broader impact of monetary policy. While there seems to be a consensus about the fact that monetary policy affects aggregate risk premia, its effects on the cross-section of risk premia are not as well understood. ${ }^{1}$

To address this question, we create a parsimonious monetary policy exposure index based on observable firm characteristics that are theoretically linked to how firms react to monetary policy. Using this index, we find that stocks whose prices react more positively to expansionary monetary policy surprises earn lower average returns, consistent with the notion that monetary policy is more likely to be expansionary in tough economic times, and hence firms with high monetary policy exposure provide a hedge against bad times. A long-short trading strategy designed to exploit this effect achieves an annualized value-weighted return of 9.96 percent with an associated Sharpe Ratio of 0.93 between 1975 and 2015.

The main challenge in studying the impact of monetary policy on the cross-section of equity risk premia arises from the difficulty in measuring firms' exposure to monetary policy. A direct approach, where one regresses individual stock returns on monetary policy surprises, is not fruitful because the majority of stocks have a very high volatility or lack a long enough history,

\footnotetext{
${ }^{1}$ The effect of monetary policy on risk premia goes back to, at least, Bansal and Coleman (1996). Bernanke and Kuttner (2005) show that a surprise 25-basis-point cut in the federal funds rate target is associated with a 1 percent increase in broad stock indices, and they attribute this increase predominantly to changes in risk premia. More recently, Uhlig (2007), Campbell, Pflueger, and Viceira (2015), Li and Palomino (2014), and Weber (2015) study the risk of equities under nominal rigidities. See also Velikov (2015) and Neuhierl and Weber (2016), who study the predictability of stock prices based on changes in the monetary policy stance.
} 
leading to imprecise coefficient estimates. Consistent with this argument, individual stocks' historical covariances with monetary policy surprises are transient in nature and do not capture future monetary policy exposure. ${ }^{2}$ In order to solve this problem, researchers have focused on portfolios based on individual characteristics. This approach has achieved only mixed success, not only because this approach depends crucially on the choice of the characteristic but also because a single characteristic is unlikely to capture the entire cross-sectional variation in the policy sensitivity of stock prices. ${ }^{3}$

Instead, we rely on the existing literature that studies the transmission channel of monetary policy to stock prices in order to capture the multidimensional nature of the cross-sectional heterogeneity in monetary policy sensitivity. For example, Bernanke and Kuttner (2005) find that stocks of firms in cyclical industries react more to monetary policy surprises. Ehrmann and Fratzcher (2004) document that S\&P 500 stocks with small size, low cash flow, poor ratings, low leverage, and low valuation are more sensitive to monetary policy. Ozdagli (2015) shows that firms with higher financial frictions react less to policy surprises. Weber (2015) documents that sticky-price firms are more exposed to monetary policy. In this study, we use the approach in the transmission channel of monetary policy literature to fill the obvious void in the asset pricing literature by building a parsimonious "monetary policy exposure" (MPE) index at the individual firm level. To this end, we regress individual stock returns around scheduled FOMC meetings on a set of firm-level characteristics that are theoretically linked to the exposure, interacted with the monetary policy surprises on those meeting dates. We then create our MPE index by adding up the product of the estimated coefficients on the interactions with the corresponding characteristics. Our approach is similar to, for example, Pastor and Stambaugh (2003) who study cross-sectional implications of liquidity risk by relating stocks' exposure to

\footnotetext{
${ }^{2}$ See Velikov (2015) for details.

${ }^{3}$ These studies typically focus on size or book-to-market. See, among others, Thorbecke (1997), Maio (2014), Buraschi, Carnelli, and Whelan (2014), and Lioui and Maio (2014). For example, Buraschi, Carnelli, and Whelan (2014) finds the opposite sign for the risk price compared with Lioui and Maio (2014) and Thorbecke (1997).
} 
liquidity risk to several characteristics and to Campbell, Hilscher, and Szilagyi (2008), who study the cross-sectional implications of distress risk by creating a financial distress index based on firm characteristics. Our approach also seems to be in line with the view of investors. ${ }^{4}$

Equipped with the MPE index, we study the asset pricing implications of monetary policy. Although several classes of theoretical models imply that monetary policy is an important source of risk in the stock market, their predictions regarding the sign of the risk premia differ widely. For example, in cash-in-advance models (for example, Bansal and Coleman 1996 and Balduzzi 2007) the sign of the risk premium depends on the elasticity of substitution between cash and credit goods. New Keynesian models (for example, Li and Palomino 2014 and Weber 2015) and intermediary asset pricing models (for example, Adrian et al. 2014 and Drechsler et al. 2015), where monetary policy is the "driver" of business cycles, suggest that tighter monetary policy increases the marginal value of wealth and therefore higher monetary policy exposure leads to a higher risk premium. On the other hand, because the goal of the central bank is to stabilize the economy by reducing rates in bad times and raising rates in good times, firms that are more responsive to policy can benefit more from the expansionary policies in bad times and therefore have lower risk premia.

To illustrate the two competing effects, we provide a simple model in which monetary policy can serve either as a "stabilizer" of business cycles (consistent with the central bank's stated objective of economic stability) or as a "driver" of business cycles. If monetary policy "drives" business cycles, an expansionary monetary policy is good news for investors, so assets that pay off in those periods are riskier and should earn higher expected returns. If, on the other hand, monetary policy is likely to be expansionary during bad times (the "stabilizer" effect) when the marginal value of consumption and wealth is high, assets that pay off in those

\footnotetext{
${ }^{4}$ For example, Research Insight from MSCI (2010) says: "Macroeconomic events, like sudden changes in interest rate, inflation, or exchange rate expectations, can affect all stocks to varying degrees, depending on the stock's characteristics." Firms also recognize monetary policy as an important source of risk. For example, Walmart's 10-K file, dated January 31, 2013, says "Our business operations are subject to numerous risks. These factors include [...] changes in the monetary policies of the United States."
} 
periods serve as a hedge and would thus require a lower expected return. Ultimately, whether monetary policy risk is priced and whether the sign of the price of this risk is positive or negative are empirical questions, which our MPE index allows us to address.

Consistent with the "stabilizer" view of monetary policy, we find that our MPE index is a strong negative predictor of returns in the cross-section of equities. Specifically, stocks with a relatively low MPE index value (that is, those that tend to perform poorly when there is an expansionary monetary policy surprise) have significantly higher average returns than firms with a high MPE index value (that is, those that tend to perform well when there is an expansionary monetary policy surprise). A long-short trading strategy designed to exploit this effect achieves an annualized return of 9.96 percent ( $t$-statistic of 5.92) with an annualized Sharpe Ratio of 0.93 between 1975 and 2015. This performance is roughly double that of other popular anomalies such as gross profitability or momentum. ${ }^{5}$

This predictability is a robust feature of the data. Popular factor models do not seem to account for it. Even after controlling for the Fama and French (2015) five-factor model, the strategy earns an annualized abnormal return of 5.88 percent ( $t$-statistic of 4.39) between 1975, the start date of reliable quarterly balance sheet data, and 2015. We also recalculate the MPE index using only historical data available to investors at the time of a given FOMC announcement. Sorting on this tradable signal generates an annualized return of 9.12 percent with a Fama and French (2015) alpha of 5.76 percent between 1996 and 2015, numbers very close to those of the full sample.

Our results do not seem to be driven by the pre-FOMC announcement drift documented by Lucca and Moench (2015). To show this, we reestimate the value-weighted portfolio returns based on the MPE index after excluding the day before and the day of every scheduled FOMC meeting, and show that the predictability still holds. In addition, because Savor and Wilson

\footnotetext{
${ }^{5}$ For the same time period, a similarly constructed, quintile value-weighted gross profitability (momentum) long/short strategy, using NYSE breakpoints, achieves an annualized Sharpe ratio of 0.37 (0.48).
} 
(2014) show that the CAPM holds on FOMC meeting days, one might be worried that our results are driven by the betting-against-beta effect discussed in Black (1972) and Frazzini and Pedersen (2014). Using double sorts on CAPM beta and MPE, we show that we are not capturing a betting-against-beta effect. This result is not surprising: the fact that CAPM holds on FOMC dates does not imply that CAPM successfully captures the reaction of stock prices to monetary policy, especially because most of the returns on FOMC dates are realized in the 24-hours before the monetary policy announcement (Lucca and Moench 2015), whereas we are interested in the stock price reaction following the monetary policy announcement.

Using double sorts, spanning tests, and Fama-MacBeth regressions, we confirm that the strategy performance continues to hold even after controlling for the underlying characteristics used to construct the monetary policy exposure index. Moreover, this pattern in the crosssection is not a different anomaly in disguise. Again using double sorts, spanning tests, and Fama-MacBeth regressions, we show that the predictability we document is independent of the 23 anomalies from Novy-Marx and Velikov (2016). Finally, we also show that the results are robust to using different monetary policy surprises or changes in the way we gauge firms' reactions to monetary policy.

Our study contributes to the literature in several ways. Inspired by the extensive corporate finance literature that generates indices of distress (for example, Altman 1968, Ohlson 1980, Dichev 1998, and Campbell et al. 2008) or financial constraints (for example, Kaplan and Zingales 1997 and Whited and $\mathrm{Wu} 2006$ ), this is the first paper to build an index of monetary policy exposure using firm characteristics. This method has an important advantage. While monetary policy surprises can be reliably estimated only after 1994, utilizing the characteristics and estimated coefficients allows us to extend the sample back to early 1970 s. ${ }^{6}$ The monetary policy exposure index we build is well grounded in theory, easy to construct, and a robust

\footnotetext{
${ }^{6}$ Before 1994, the timing of rate changes was ambiguous, because the FOMC's policy did not involve announcing target rate changes at pre-scheduled dates.
} 
predictor of returns in the cross-section.

More importantly, we build a bridge between the literature that connects firm characteristics to their expected returns, as in Fama and French (1993), and the literature that studies macroeconomic aggregates as predictors of asset returns, as in Lettau and Ludvigson (2001), Adrian, Etula, and Muir (2014), and Gao et al. (2016). Even though there has been an extensive theoretical literature that studies the impact of monetary policy on risk premia, the empirical evidence has been scant. Building the index of monetary policy exposure allows us to test the predictions of different classes of theoretical models and show that monetary policy exposure is a strong predictor of returns in the cross-section of equities. Moreover, while the recent literature has become skeptical of new sources of predictability in the cross-section of stock returns, our monetary policy exposure index is theoretically motivated and our results are robust to the stricter thresholds for statistical significance suggested by Harvey, Liu, and Zhu (2016) and Novy-Marx (2016).

\section{Theoretical Considerations}

Standard asset pricing theory tells us that the risk premium of monetary policy is the product of the price of monetary policy risk and exposure to monetary policy. In this section, we summarize the implications of different theories for these two components and show that the monetary policy risk premium can be positive or negative depending on the underlying assumptions. Therefore, we conclude that determination of this risk premium is an empirical question on which we focus in the following sections. 


\subsection{The Price of Monetary Policy Risk}

\subsubsection{Early Models: The Cash-in-Advance Constraint}

Bansal and Coleman (1996) and Chan, Foresi, and Lang (1996) are two early examples that analyze the effect of monetary policy on equity premia. Both of these models feature cash-inadvance constraints from the seminal paper of Lucas and Stokey (1987). The information in these papers is later crystallized in Balduzzi (2007), which shows that the price of monetary policy risk depends on the elasticity of substitution between cash and credit goods. To see this, suppose the preferences are given by

$$
E_{t}\left(\sum_{s=0}^{\infty} \beta^{s} U\left(c_{1 t+s}, c_{2 t+s}\right)\right)
$$

where $c_{1}$ is the cash good and $c_{2}$ is the credit good and total output is $y=c_{1}+c_{2}$. Under the common assumption that the cash-in-advance constraint is binding, the consumption of the cash good is equal to real money balances, $m$.

In this framework, the stochastic discount factor, $\Lambda_{t+1}$, is determined by the marginal utility of credit good, $U_{c_{2}}$, that is,

$$
\Lambda_{t+1}=\frac{\beta U_{c_{2}}\left(c_{1 t+1}, c_{2 t+1}\right)}{U_{c_{2}}\left(c_{1 t}, c_{2 t}\right)}=\frac{\beta U_{c_{2}}\left(m_{t+1}, y-m_{t+1}\right)}{U_{c_{2}}\left(m_{t}, y-m_{t}\right)} .
$$

For a given level of output, $y$, an expansionary policy (increase in real money balances, $m_{t+1}$ ) makes consumers substitute away from the credit good, and the net effect on the stochastic discount factor will be driven by $U_{c_{2} c_{1}}-U_{c_{2} c_{2}}$. When $U_{c_{2} c_{1}}-U_{c_{2} c_{2}}<0$, the price of an expansionary monetary policy surprise is negative, that is, assets that pay off in monetary expansions are hedges, and when $U_{c_{2} c_{1}}-U_{c_{2} c_{2}}>0$, the price of monetary policy risk is positive, that is, assets that pay off in monetary contractions are hedges. Therefore, in cash-in-advance models, monetary policy commands a risk premium even in the absence of any real effects 
on output, and this risk premium can be positive or negative depending on the substitutability between cash and credit goods, regardless of the effect of monetary policy on output. In this model, any effect of monetary policy on output would also affect the price of monetary policy risk but would not resolve the ambiguity of the theoretical implications.

\subsubsection{Modern Models: New-Keynesian and Funding Liquidity Models}

More recently, the New Keynesian monetary models that incorporate nominal and real rigidities have received increasing attention in the literature studying the risk of equities, for example, Li and Palomino (2014) and Weber (2015). ${ }^{7}$ In these two models, consumption and leisure are additively separable; hence, an expansionary policy surprise increases consumption and decreases the marginal utility thereof, leading to a positive risk price for monetary policy. Therefore, stocks that react more positively to an expansionary policy surprise should command a higher risk premium. If, on the other hand, consumption and leisure are substitutes, an increase in leisure following a contractionary surprise can reduce the marginal utility of consumption, leading to a negative risk price of monetary policy surprises.

In another recent strand of literature, a growing number of papers study asset pricing implications of macroeconomic models with financial frictions, such as those in Bernanke and Blinder (1988). The central theme of this literature is that the marginal investor is likely a financial intermediary, so the stochastic discount factor should depend on the health of the financial sector, or funding liquidity, which determines the marginal value of wealth. Thus, assets that pay off in times of high marginal value of wealth, that is, in times with low funding liquidity, should be less risky. ${ }^{8}$ Empirically, Adrian, Etula, and Muir (2014) show that a singlefactor model consisting of security broker-dealers' leverage explains a large fraction of returns

\footnotetext{
${ }^{7}$ See also Uhlig (2007) and Campbell, Pflueger, and Viceira (2015).

${ }^{8}$ These papers differ in the proxy they use for times of a high marginal value of wealth. For example, $\mathrm{He}$ and Krishnamurthy (2013) and Brunnermeier and Sannikov (2014) use the equity of financial intermediaries while Brunnermeier and Pedersen (2009), Geanakopoulos (2009), and Adrian and Boyarchenko (2012) feature intermediary leverage as the relevant proxy for funding liquidity.
} 
of size, value, momentum, and treasury portfolios. Drechsler, Savov, and Schnabl (2015) provide a dynamic asset pricing model linking equity risk premia to monetary policy through this funding liquidity channel. In their model, lowering the nominal interest rate reduces the cost of leverage and effectively reduces the external finance premium, increasing risk taking and, in turn, decreasing the risk premia.

Both the New Keynesian models and the funding liquidity model operate under the view that monetary policy is a driver of business cycles; that is, monetary policy affects the marginal value of wealth by affecting real variables, which in turn transform it into a source of priced risk. An alternative view arises from viewing the monetary policy as a stabilizer of business cycles. In particular, monetary policy is more likely to be expansionary during bad times, when the marginal value of wealth is high. The assets that are more likely to pay off after an expansionary monetary policy are precisely those that provide investors with additional funds in times of need and therefore have a lower risk premium. This view seems to be more in line with the role of the Federal Reserve in stabilizing the economy. ${ }^{9}$

\section{A Simple Illustration of the Driver vs. Stabilizer Effect of Monetary Policy}

Here, we outline a simple mathematical model that illustrates the driver and stabilizer effects in a consumption-CAPM framework where the stochastic discount factor is negatively related to consumption, which captures the gist of the more-complicated New Keynesian models of Li and Palomino (2014) and Weber (2015). The same ideas can also be applied to a funding liquidity model where the stochastic discount factor is negatively related to the procyclical funding liquidity of financial intermediaries.

For simplicity, we assume that we live in an endowment economy such that consumption

\footnotetext{
${ }^{9}$ Note that this is different from the signalling channel of monetary policy where an increase in the interest rate reveals good news about the future of the economy, as in Romer and Romer (2000), Campbell et al. (2012), and Nakamura and Steinsson (2015). While the signaling channel would also imply a negative risk price of an expansionary surprise, the intuition is actually closer to that of long-run risk models, where positive interest rate surprises are generally good news, which makes long-duration assets, which are more interest sensitive, valuable hedges, reducing their risk premia.
} 
is equal to output, $y_{t}$, and that it follows a diffusion process in continuous time, given by,

$$
\frac{d y_{t}}{y_{t}}=\mu d t+\theta_{y} d w_{y}
$$

where $\mu$ is the drift, $d w_{y}$ is the Brownian increment (shock), and $\sigma_{y}$ is the standard deviation of these shocks to output growth. ${ }^{10}$ Output is affected both by real shocks, $d w_{A}$, and by changes in monetary policy, $d m$, so that

$$
\theta_{y} d w_{y}=\theta_{A} d w_{A}+\theta_{M} d m
$$

from which we have

$$
\frac{d y_{t}}{y_{t}}=\mu d t+\theta_{A} d w_{A}+\theta_{M} d m
$$

where both $\theta_{A}$ and $\theta_{M}$ are positive, so an increase in money supply (or reduction in the interest rate) increases output. ${ }^{11}$

Moreover, changes in monetary policy are driven by real shocks, $d w_{A}$, and pure policy shocks uncorrelated with real shocks, $d w_{M}$, that is,

$$
d m=-\eta_{A} d w_{A}+\eta_{M} d w_{M}
$$

where $-\eta_{A}<0$ captures the stabilizer effect, the fact that monetary policy tightens in response to expansionary real shocks $\left(d w_{A}>0\right)$, and $\eta_{M}>0$ captures the effect of expansionary pure policy surprises $\left(d w_{M}>0\right)$. Without loss of generality, we are assuming that $\eta_{A}^{2}+\eta_{M}^{2}=1$, so that $d m$ has a unit variance, which simplifies our calculations below.

\footnotetext{
${ }^{10}$ We omit time-subscripts throughout for the sake of parsimony. Similar results can be obtained with discrete time using the log-normal approximation in Cochrane (2001). We use continuous time, as it yields closed-form solutions without any approximation.

${ }^{11}$ We use the notation, $m$, to be consistent with the previous section. All results follow through if we instead model interest rate decisions as $d i=-d m$, so that a higher rate implies a contractionary policy.
} 
Assuming constant relative risk aversion preferences with a relative risk aversion coefficient of $\gamma$ and discount rate $\rho$, the stochastic discount factor between time zero and $t$ becomes $\Lambda_{0, t}=$ $\exp (-\rho t) c_{t}^{-\gamma} / c_{0}^{-\gamma}=\exp (-\rho t) y_{t}^{-\gamma} / y_{0}^{-\gamma}$, which leads to the diffusion process

$$
\begin{aligned}
\frac{d \Lambda}{\Lambda} & =-\left(\rho+\gamma\left(\mu-\frac{1}{2} \theta_{y}^{2}\right)-\frac{1}{2} \gamma^{2} \theta_{y}^{2}\right) d t-\gamma \theta_{y} d w_{y} \\
& =-\left(\rho+\gamma\left(\mu-\frac{1}{2} \theta_{y}^{2}\right)-\frac{1}{2} \gamma^{2} \theta_{y}^{2}\right) d t-\gamma\left[\left(\theta_{A}-\eta_{A} \theta_{M}\right) d w_{A}+\eta_{M} \theta_{M} d w_{M}\right]
\end{aligned}
$$

Stocks react both to real shocks and changes in money supply; that is, for a stock $i$, we have

$$
\begin{aligned}
d R_{i} & =\left(r+\phi_{i}\right) d t+\sigma_{A, i} d w_{A}+\sigma_{M, i} d m+\sigma_{i} d w_{i} \\
& =\left(r+\phi_{i}\right) d t+\left(\sigma_{A, i}-\eta_{A} \sigma_{M, i}\right) d w_{A}+\sigma_{M, i} \eta_{M} d w_{M}+\sigma_{i} d w_{i}
\end{aligned}
$$

where $r d t=-E(d \Lambda / \Lambda), \sigma_{A, i}$ and $\sigma_{M, i}$ capture the exposure of stock $i$ to real shocks and policy changes respectively, and $d w_{i}$ is the individual (non-systematic) risk of the stock. ${ }^{12}$

The term $\phi_{i}$ captures the risk premium given by the product of the price and quantity of risk,

$$
\begin{aligned}
\phi_{i} & =-\frac{1}{d t} E_{t}\left[\frac{d \Lambda}{\Lambda} d R_{i}\right] \\
& =\sigma_{A, i} \gamma \theta_{A}+\sigma_{M, i} \gamma \theta_{M} \\
& =\gamma\left(\sigma_{A, i}-\eta_{A} \sigma_{M, i}\right)\left(\theta_{A}-\eta_{A} \theta_{M}\right)+\gamma \sigma_{M, i} \eta_{M}^{2} \theta_{M} .
\end{aligned}
$$

\footnotetext{
${ }^{12}$ Our empirical approach allows us to find $\sigma_{M, i}$ by identifying pure policy shocks, $d w_{M}$, following the method of Bernanke and Kuttner (2005) as discussed in section 4
} 
Hence, the effect of monetary policy exposure on the risk premium is given by

$$
\begin{aligned}
\frac{\partial \phi_{i}}{\partial \sigma_{M, i}} & =\gamma\left[-\eta_{A}\left(\theta_{A}-\eta_{A} \theta_{M}\right)+\eta_{M}^{2} \theta_{M}\right] \\
& =\gamma\left[\theta_{M}-\eta_{A} \theta_{A}\right],
\end{aligned}
$$

where the second line follows from $\eta_{A}^{2}+\eta_{M}^{2}=1$. Here, the first term in square brackets captures the driver effect that works through the effect of monetary policy on real variables as in New Keynesian models, whereas the second term captures the stabilizer effect of monetary policy that works through the contractionary response of monetary policy to expansionary real shocks. The net effect will depend on whether the driver effect, $\gamma \theta_{M}$, is dominated by the stabilizer effect, $\gamma \eta_{A} \theta_{A} \cdot{ }^{13}$

\subsection{Theories of Exposure to Monetary Policy}

Monetary policy has a large effect on stock prices, and this effect varies significantly across firms, consistent with the fact that there are many channels that work heterogeneously for firms with different characteristics. We give the definitions of these characteristics in Appendix A and briefly discuss below the theory underlying the choice of these particular characteristics.

Financial Constraints (Credit Channel): The effect of firms' financial constraints on monetary policy transmission has been at the heart of the policy and academic discussions. ${ }^{14}$ While there is an expansive literature focusing on the implications of this credit channel on real variables, the evidence on stock prices has been relatively scarce. Perez-Quiros and Timmermann (2000) use smaller firm size as a financial constraint measure and find that stock prices of smaller firms are more responsive to monetary policy, measured by money supply. Lamont,

\begin{tabular}{|l|}
\hline${ }^{13}$ Moreover, we also see that even the conditional version of the standard CAPM would not capture the risk \\
premia correctly, since we have two aggregate shocks, $d w_{A}$ and $d w_{M}$. \\
\hline${ }^{14}$ See Gertler and Gilchrist (1994) for the seminal empirical paper in this literature; however, the theory of this \\
\hline credit channel goes back earlier. \\
\hline
\end{tabular}


Polk, and Saa-Requejo (2001) recognize that modern monetary policy is characterized by the choice of policy rates, rather than by money supply, but do not find any significant relationship between financial constraints and the policy sensitivity of stock prices when they use the change in the policy rate. Ozdagli (2015) uses the unexpected component of the policy rate change as in Bernanke and Kuttner (2005) because stocks should not react to expected changes in monetary policy. He finds that more-constrained firms can be less responsive to monetary policy because these firms rely less on external finance, and hence are less affected by the cost of external finance. ${ }^{15}$ We use a firm's percentile rank according to the financial constraint index created by Whited and Wu (2006) as our financial constraint proxy. Our choice of rank stems from the common practice in the literature that discretely separates the firms into financially constrained and unconstrained groups using financial constraint proxies, a practice that we take to the limit with percentile rank.

Cash and Short-Term Investments (Liquidity Effect): These are the most liquid assets of the firm and are directly related to the monetary base, broadly defined. On the one hand, if firms keep their cash in a non-interest-bearing account, stocks of firms with higher amount of cash can react more negatively to an interest rate increase because the interest rate is the opportunity cost of holding cash. On the other hand, if they deposit their cash in a short-term savings or another interest-bearing account, an increase in the interest rate can actually help them obtain additional liquid funds.

Cash-Flow Duration (Discount Rate Effect): While duration has been a construct widely employed by fixed-income analysts due to its clear relationship to the interest rate sensitivity of bond prices, the application to equity markets has only recently been studied by Dechow, Sloan, and Soliman (2004). Firms that expect to have cash flows farther in the future, and

\footnotetext{
${ }_{15}$ Ozdagli (2015) also shows that the relationship between stock prices and monetary policy does not need to mirror the relationship between investment and monetary policy. This is because market value of equity is the value function of a firm's optimization problem where investment is the choice variable, and there is no theoretical basis that a value function and a choice variable should move in the same direction.
} 
therefore have greater equity duration, would be more affected by an increase in interest rates because later cash flows are discounted at a higher rate.

Cash-Flow Volatility: Cash-flow volatility may capture the monetary policy sensitivity of a firm's stock price in multiple ways. For example, volatility can be related to cash-flow duration and can capture aspects thereof not perfectly captured by standard cash-flow duration measures. On the one hand, firms with lower volatility may have lower default likelihood and therefore longer lives and high duration of cash flows. On the other hand, a lower volatility may also imply a lower value of the option to delay investment and therefore firms with lower volatility may increase their cash-flow duration by increasing investment today in exchange for cash flows in the future. As another example of the importance of volatility, higher cash-flow volatility may imply that the firm needs to rely on external financing more often, and therefore may increase the importance of the cost of external financing, which is directly affected by monetary policy.

Operating Profitability (Nominal Rigidities): Nominal frictions in the form of sticky prices and wages are an important ingredient in the New-Keynesian macroeconomic models. While the data on price stickiness at the firm level is difficult to find for the majority of firms, operating profitability can still provide a window into the effects of sticky prices. ${ }^{16}$ In particular, if the input prices, for example, wages, are sticky, an expansionary monetary policy will have a large effect on the revenues of the firm without changing the total cost of inputs as much, driving stock prices upward. The resulting percentage increase in the stock price will be stronger for firms whose revenues are closer to their input costs, that is, those that have low profitability, because of the operating leverage effect created by the relatively fixed input costs. In contrast, following an analogous intuition, if a firm's output prices are stickier than its input prices, an expansionary monetary policy will lead to a greater increase in input costs than in the

\footnotetext{
${ }^{16}$ An important exception for firm-level price stickiness data is Weber (2015), who uses hand-collected data for S\&P 500 firms. He finds that firms with high price stickiness have higher returns but that these return differentials can be explained by CAPM $\beta$.
} 
firm's revenues, eating away the firm's profits, but to a smaller degree (in percentage terms) for firms with greater profitability. More recently, Gomes, Jermann, and Schmid (2016) provide a mechanism where expansionary monetary policy reduces firms' real debt burden due to their nominal obligations to lenders. This "sticky leverage" mechanism works in a way similar to the sticky wage channel above in that sticky wages reduce the real burden of nominal obligations to a firm's employees after an expansionary policy. Therefore, we expect sticky leverage to amplify the effects of sticky wages.

Other: We also control for industry effects but do not include this in our MPE index, to keep the index parsimonious. We also include firm ratings in our estimation sample, the 19942008 period for which we have the Bernanke-Kuttner surprises, but we do not use them in our index because the ratings information does not go back to 1975, when our full sample analysis starts.

\section{Data}

We use the standard approach in the literature by using CRSP for stock returns and COMPUSTAT for the firm-level variables underlying the characteristics we discussed in the last section. A detailed definition of these characteristics, along with the variables we use from the CRSP/COMPUSTAT Merged database, are given in Appendix A.

Following Kuttner (2001), Bernanke and Kuttner (2005), and Gürkaynak, Sack, and SwanSon (2005; 2007) we measure policy surprises as the unexpected component of the federal funds target rate change due to target rate announcements on the day of FOMC meetings as captured by federal funds futures. We focus on scheduled FOMC meetings between February 1994 and June 2008. Starting in February 1994, the FOMC's policy of announcing target rate changes at pre-scheduled dates virtually eliminated the timing ambiguity associated with rate changes prior to this date. We end in mid-2008, because this is when the federal funds target 
rate reaches the zero lower bound. ${ }^{17}$ We use the intraday "tight" surprise measure from Gürkaynak, Sack, and Swanson (2005) because these authors show that occasionally macroeconomic news earlier in the day can change investors' expectations about an FOMC announcement later in the day and hence create noise in the policy surprise measure. ${ }^{18}$

For an FOMC meeting happening on day $d$ of month $m$, with the public announcement at $2: 15 \mathrm{pm}$, the surprise change in the federal funds rate is given by:

$$
\Delta i_{G S S, t i g h t}=\frac{D}{D-d}\left(f_{m, d, \text { Post 2:35 pm }}^{0}-f_{m, d, \text { Pre 2:05 pm }}^{0}\right)
$$

where $D$ is the number of days in the month and $f_{m, d}^{0}$ is the federal funds rate implied by the federal funds future expiring in the current month. The measure equals the difference between the current month federal funds rate implied by the price of the first futures trade after 2:35 $\mathrm{pm}$, and the same rate implied by the price of the last trade before 2:05 pm. For those cases where the scheduled announcements is not at 2:15 pm, the 30 -minute event window is shifted accordingly. Following Bernanke and Kuttner (2005), our identification of monetary policy exposure comes from regressing the returns around the scheduled FOMC announcement on the surprise component of policy rate change on that announcement date. ${ }^{19}$

We prefer this approach to calculate policy surprises because previous literature finds that federal funds futures outperform target-rate forecasts based on other financial market instru-

\footnotetext{
${ }^{17}$ See Gürkaynak, Sack, and Swanson (2007) for details. Given the Fed's recent move toward policy normalization, this will be the more relevant policy measure for the future as well.

${ }^{18}$ In a worst-case scenario, using daily surprises can also lead to an omitted variable bias. For example, if there is an announcement of the unemployment rate in the morning and a policy rate announcement in the afternoon, the daily policy surprise measure will be the sum of the reaction of the FOMC to the unemployment announcement and the true policy surprise conditional on the effect of the unemployment announcement on the FOMC decision. If, realistically, the unemployment announcement has a direct effect on daily stock prices, using daily surprises as in Bernanke and Kuttner (2005), instead of intraday surprises as in Gürkaynak, Sack, and Swanson (2005), can bias our estimates. We would like to thank Refet Gürkaynak for sharing his updated dataset with us.

${ }^{19}$ We drop the FOMC announcement on March 18, 2008, as an outlier because on that day, the S\&P 500 index increased by about 4 percent despite a 17 (10) basis points contractionary daily (intraday) policy surprise, reflecting the positive news about JP Morgan's purchase of Bear Stearns. Including this date changes the sensitivity of the daily CRSP value-weighted index to a 1 percentage point daily policy surprise from about 3.5 percent, in line with earlier estimates of Bernanke and Kuttner (2005), to 1.5 percent.
} 
ments or based on alternative methods, such as sophisticated time series specifications and monetary policy rules. ${ }^{20}$ Another advantage of looking at intraday changes in near-dated federal funds futures is that federal funds futures do not exhibit predictable time-varying risk premia and forecast errors over such high frequencies. ${ }^{21}$

\section{Monetary Policy Exposure Estimation}

An important challenge to calculating the monetary policy exposure of individual stocks comes from the fact that many stocks have very high volatility and lack a long enough history, leading to imprecise coefficient estimates when one simply runs a regression of individual stock returns on policy surprises. Instead, we note that the literature has identified various firm characteristics that influence stocks' reaction to monetary policy surprises, and we use the interaction of these characteristics with policy surprises as explanatory variables. Our main specification is

$$
r_{i t}=\alpha+\Sigma_{k=1}^{n} \beta_{k} x_{i t}+\Sigma_{k=1}^{n} \gamma_{k} M P S_{t} \times x_{i t}+\text { Controls }_{i t}+\varepsilon_{i t},
$$

where $t$ is the date of the scheduled FOMC meetings, $r_{i t}$ is the stock return surrounding these FOMC meetings, and $x_{i t}$ are the firm characteristics that capture the exposure of a firm to monetary policy, as discussed in section 2.2. $M P S_{t}$ is the monetary policy surprise due to FOMC announcements on these meeting dates; $M P S_{t}=-\Delta i_{G S S, t i g h t}$, so a positive surprise is expansionary. Controls ${ }_{i t}$ include meeting, industry, and rating fixed effects, as well as interactions of the industry and rating fixed effects with the monetary policy surprises. The regressions are estimated at the meeting-firm level.

Table 1 presents the results regarding how different characteristics capture the exposure of stock prices to monetary policy. Following Ippolito, Ozdagli, and Perez (2015), we focus

\footnotetext{
${ }^{20}$ See Evans (1998) and Gürkaynak, Sack, and Swanson (2007).

${ }^{21}$ See, for example, Piazzesi and Swanson (2008).
} 
on two-day returns to allow sufficient time for the stocks to react to monetary policy while still staying within the two-day blackout period that follows an FOMC meeting in order to avoid contamination by other FOMC-related news. ${ }^{22}$ The first column gives the unconditional relationship and shows that a 1 percentage point expansionary surprise (reduction in the federal funds target rate) leads, on average, to a 5 percent increase in stock prices, consistent with earlier results in Bernanke and Kuttner (2005) and Gürkaynak, Sack, and Swanson (2005). Column 2 shows that higher cash holdings lead to lower stock price sensitivity to monetary policy, consistent with the notion that short-term deposits in interest-bearing accounts provide a hedge against interest rate changes. Column 3 shows that, consistent with our intuition, firms with higher cash-flow duration are more responsive to surprise changes in the federal funds target rate. Column 4 presents the effect of financial constraints: consistent with Ozdagli (2015), stock prices of more constrained firms, that is, those with a higher Whited-Wu measure, are less responsive to monetary policy surprises. Column 5 shows that firms with greater cashflow volatility are more responsive to monetary policy surprises. Column 6 shows that firms with higher operating profitability are less responsive to monetary policy, consistent with the intuition that sticky input prices, such as wages, or sticky leverage, as in Gomes, Jermann, and Schmid (2016), may lead to lower sensitivity of firm's profits to changes in input prices.

Finally, the second to last column of Table 1 puts all these variables together and shows that the coefficients preserve most of their size and significance. Using the estimates in column 7, our monetary policy exposure (MPE) index becomes:

\footnotetext{
${ }^{22}$ In Greenspan's words about the post-FOMC blackout period, "the thrust of the announced decision of the Committee then gets diluted." https://www.federalreserve.gov/monetarypolicy/files/ FOMC19950201meeting.pdf. Section E of the online appendix shows that the main results are robust to alternative windows after the announcement.
} 


$$
\begin{aligned}
\mathrm{MPE}=-4.99 & \times \text { Cash }+1.75 \times \text { CF Duration Rank }-2.10 \times \text { Whited-Wu Rank } \\
& +9.26 \times \text { CF Volatility }-11.84 \times \text { Operating Profitability } .
\end{aligned}
$$

The last column uses this index directly as a regressor interacted with monetary policy surprise; we see that it is highly significant, with a $t$-statistic of 9.23. Note that while we have used Ratings and Industry Fixed Effects interacted with monetary policy surprise (MPS) as additional controls, we do not include them in our MPE index. Ratings were seldom available for firms toward the beginning of our sample period for asset pricing tests, which starts in 1975; omitting industry effects allow us to focus on cross-sectional differences in stock returns that go beyond differences in industry returns and keep our index parsimonious.

\subsection{External Validity: Forward Guidance}

In the previous section, we have followed in the footsteps of Bernanke and Kuttner (2005) and used the monetary policy surprises implied by federal funds futures to estimate our monetary policy exposure index. However, the nature of monetary policy has changed since 2008, when short-term rates hit the zero lower bound (ZLB). During this period, the policy surprise measures based on current-month federal funds futures are uninformative because monetary policy actions did not have any significant effect on short-term rates but instead influenced the expectations of longer-term rates through large-scale asset purchases and forward guidance. Therefore, we are interested in how well our monetary policy exposure index does in the recent ZLB period, to provide evidence for the external validity of our MPE measure.

We follow Rigobon and Sack (2004) and Gürkaynak, Sack, and Swanson (2005) and use Eurodollar (ED) futures with maturities ranging from one to eight quarters, in order to measure 
the change in expectations about future interest rate decisions of the FOMC. ${ }^{23}$ For an FOMC meeting happening on day $d$ of month $m$, the forward guidance surprise (FGS) for the next $X$ quarters is given by:

$$
F G S X=-\left(E D X_{d, m, \text { Post 2:35 pm }}-E D X_{d, m, \text { Pre 2:05 pm }}\right)
$$

where $E D X$ is the 3-month Eurodollar futures rate maturing $X$ quarters ahead. The measure equals the difference between the $X$-quarter-ahead 3-month Eurodollar futures rate implied by the price of the first trade after 2:35 pm, and the same rate implied by the price of the last trade before 2:05 pm. If our MPE index has any merit, we should find that firms with a high MPE respond more strongly to these policy-induced surprises to rate expectations, which we call ZLB surprises. Moreover, the effect of these ZLB surprises should be stronger for the longer-term rates on which the unconventional monetary policy has focused. Table 2 provides regressions similar to the one in the last column of Table 1 using these ZLB surprises. Consistent with our intuition, the size and significance of the interaction term between MPE and the ZLB surprises become greater as we go from surprises to short-term rate expectations, captured by FGS1, to longer-term expectations, captured by FGS8. Moreover, the coefficients for FGS5 to FGS8 are very close to 1 as in the last column of Table 1 . Overall, these results confirm the validity of our MPE index outside of the period used for its estimation, thereby providing support for its external validity.

\section{Asset Pricing Implications}

Equipped with our monetary policy exposure (MPE) index, in this section we explore the asset pricing implications of monetary policy. Table 3 reports average value-weighted excess returns, alphas, and loadings on the five factors from the Fama and French (2015) five-factor model

\footnotetext{
${ }^{23} \mathrm{ED}$ futures capture the expectations of the 3-month LIBOR at the maturity date of these futures.
} 
for five portfolios constructed by sorting stocks based on their monetary policy exposure, as well as a portfolio that is long stocks in the lowest quintile of monetary policy exposure and short stocks in the highest quintile of monetary policy exposure. Monetary policy exposure is estimated using equation (3) from Section 4. In each month, firms are grouped into quintiles based on their monetary policy exposure using NYSE breakpoints. While data on the monetary policy surprises are available only for the shorter period used for the estimation of the monetary policy index in Table 1, data on the the characteristics used to construct the monetary policy exposure index are available going back to January 1975 and up to December 2015, so we use this longer period for the asset pricing tests.

Panel A of Table 3 documents the excess returns and alphas of the six portfolios. We observe a monotonically decreasing pattern in the average returns to the first five portfolios. The long/short portfolio achieves an annualized average return of about 10 percent $(0.83 * 12)$, with an associated $t$-statistic of 5.92. The annualized Sharpe ratio is 0.93 . The strategy continues to generate significant returns even after controlling for standard factor models. Controlling for market returns does not affect the spread, as evidenced by the CAPM alpha of 80 basis points per month, an estimate that is more than five standard errors above zero. Adding the Fama and French (1993) SMB and HML factors decreases the abnormal return to about 51 basis points ( $t$-statistic of 4.65). Adding the Carhart (1997) momentum factor does not affect the significance of the alpha on the long/short portfolio, and even after controlling for the five factors in the Fama and French (2015) model, we are left with an alpha of 49 basis points per month, which is more than four standard errors above zero, corresponding to an annualized information ratio of 0.73 .

While a significant proportion of the returns to the long/short strategy in Panel A is left unexplained by the five-factor model, the decrease in its performance can be attributed to the significant loadings on the SMB and HML factors. Panel B reports the loadings of the six portfolios from Panel A on the Fama and French (2015) five factors. We observe that the 
long/short portfolio has significant loadings of 0.63 ( $t$-statistic of 15.71) and 0.43 ( $t$-statistic of 8.29) on the SMB and HML factors, respectively. These loadings are not surprising, given that the monetary policy index employs the Whited-Wu index and CF Duration. Stocks with a low MPE tend to be more financially constrained and to have lower cash-flow duration. Dechow, Sloan, and Soliman (2004) and Weber (2016) show that cash-flow duration is negatively related to book-to-market, which explains the value tilt of the strategy, while log of total assets negatively enters the Whited-Wu index, which explains the size tilt of the strategy.

We now turn our attention to robustness tests.

\subsection{Fama-MacBeth Regressions}

Table 4 reports results from estimating Fama-MacBeth regressions of firms' returns on monetary policy exposure and controls. The controls include size $(\log (\mathrm{ME}))$, book-to-market $(\log (\mathrm{BM}))$, gross profitability (GP/A), investment (I/A), and past performance measured at horizons of 12 to one month $\left(r_{12,1}\right)$ and one month $\left(r_{1,0}\right) \cdot{ }^{24}$ The tests cover January 1975 to December 2015. The sample excludes financial firms. Independent variables are winsorized at the 1 percent and 99 percent levels.

The first specification shows, consistent with the portfolio sorts, that current-month MPE is strongly negatively associated with average returns over the next month. The relation is strongly significant, with a $t$-statistic of -12.99 . Specifications (2)-(7) add control variables popularly used in the literature, one at a time, and in all of them MPE preserves its strong

\footnotetext{
${ }^{24}$ Book-to-market is book equity scaled by market equity, where market equity is lagged six months following Fama and French (1993). Book equity is shareholder equity plus deferred taxes minus preferred stock, when available. Stockholders' equity is as given in Compustat (SEQ) if available, or else common equity plus the carrying value of preferred stock (CEQ + PSTX), if available, or else total assets minus total liabilities (AT - LT). Deferred taxes is deferred taxes and investment tax credits (TXDITC), if available, or else deferred taxes and/or investment tax credit (TXDB and/or ITCB). Prefered stock is redemption value (PSTKR), if available, or else liquidating value (PSTKRL), if available, or else carrying value (PSTK). Gross profitability is defined as total revenue (REVT) minus cost of goods sold (COGS), scaled by total assets (AT). Investment is defined as growth in total assets (AT).
} 
predictive power. Moreover, the loadings on $\log (\mathrm{ME})$ in specification (2), $\log (\mathrm{BM})$ in specification (3), and GP/A in specification (4) are not statistically significantly different from zero, indicating that MPE subsumes their predictability. This shows the power of our MPE index, given that we build it to be a good predictor of monetary policy exposure rather than a predictor of stock returns. Specification (8) shows that all the controls significantly predict returns. More importantly, specification (9) demonstrates that MPE has predictive power for the cross-section of average returns beyond that in all of the controls. Consistent with specifications (2)-(4), the loadings on $\log (\mathrm{ME}), \log (\mathrm{BM})$, and GP/A in specification (9) are not reliably different from zero. The $t$-statistic on MPE is roughly of the same size as the one on $r_{1,0}$, double the one on I/A, and about four times the one on $r_{12,1}$. These results confirm the robustness of the results in Table 3 .

\subsection{Out-of-sample Portfolio Performance}

Despite the strong predictive performance of monetary policy exposure in Tables 3 and 4 . the strategy from Table 3 is not implementable if investors are not fully aware of the datagenerating process of the underlying variables, because it uses information that would not have been available to them at the beginning of the sample. To address this concern, this section presents an out-of-sample test using only historically available information. That is, monetary policy exposure is estimated using expanding windows, including only FOMC meetings prior to the portfolio formation month. The sample begins in August 1996, using 20 FOMC meetings between February 1994 and July 1996. Following June 2008, all 115 meetings between February 1994 and June 2008 are included for the estimation of the coefficients used in the construction of MPE.

Table 5 shows that the average returns and alphas generated by this implementable strategy are very close to the full-sample ones reported in Table 3. The expanding windows strategy 
generates 0.76 percent per month compared with 0.83 percent per month for the full sample. The five-factor alpha for the expanding windows strategy is 0.48 percent per month compared with 0.49 percent per month for the full sample. The slightly lower statistical significance for the out-of-sample test can be attributed to the shorter length of the sample period. More importantly, this strategy is a low-cost implementable strategy that exhibits fairly low buy and sell turnover of about 11 percent per month, which is comparable with the low turnover strategies from Novy-Marx and Velikov (2016). The transaction costs, measured following Novy-Marx and Velikov (2016), are 16 basis points per month, resulting in a net average return to the long/short portfolio of 60 basis points with a $t$-statistic of $2.46 .^{25}$ The Novy-Marx and Velikov (2016) "generalized alpha" with respect to the Fama and French (2015) five-factor model equals 0.49 percent per month ( $t$-statistic of 2.80$).{ }^{26}$

\subsection{Robustness to pre-FOMC drift}

A potential concern with looking at the stock market reactions to scheduled FOMC meetings is the extent to which results are driven by the strong market returns on FOMC days documented by Savor and Wilson (2013) or the pre-FOMC drift documented by Lucca and Moench (2015).

Thus, to alleviate this concern, Table 6 replicates the analysis in Table 3 using the same MPE index, but excludes the returns for all stocks on the day prior to and on the date of scheduled FOMC meetings. ${ }^{27}$ That is, for months with FOMC meetings, all stocks are assumed to have zero returns on the day before the FOMC meeting and on the day of the FOMC meeting. We see that using the adjusted returns does not weaken the predictability of monetary policy exposure.

\footnotetext{
${ }^{25}$ For the same period, a value-weighted momentum long/short strategy based on a quintile sort with NYSE breakpoints earns an insignificant average net return of 19 basis points per month ( $t$-statistic of 0.43 ).

26 Novy-Marx and Velikov (2016) develop the "generalized alpha" in order to test whether a test asset improves the investment opportunity set available to investors when trading is costly. In this case, it is defined as the average abnormal return to the mean-variance efficient portfolio of the net MPE strategy and the net Fama and French (2015) five factors, levered to hold one dollar of the MPE strategy, relative to the return to the mean-variance efficient portfolio of the net Fama and French (2015) five factors alone.

${ }^{27}$ We get the scheduled FOMC dates from https://fraser.stlouisfed.org/title/677.
} 
If anything, the average returns and alphas of the long/short portfolio are somewhat higher. Excluding days -1 and 0 around FOMC days results in an average monthly return of 0.84 percent $(t=6.23)$ compared with 0.83 percent $(t=5.92)$ without excluding them (Table 3), and a Fama and French (2015) alpha of 0.52 percent $(t=4.68)$ compared with 0.49 percent $(t=4.39)$ in Table 3 . Thus, the evidence indicates that the monetary policy risk premium we document is not accrued only around FOMC meetings, which is consistent with the notion that investors require a premium to hold stocks that perform poorly in times of expansionary monetary policy surprises.

\subsection{Robustness to Betting Against the Beta Effect}

Another concern with looking at the stock market reactions to scheduled FOMC meetings is that stocks' reactions to the surprises could be captured by their exposure to the aggregate market. Savor and Wilson (2014) document that the CAPM works well on days with scheduled macroeconomic announcements. If high MPE stocks are high beta stocks, it is possible that we are just capturing a betting-against-beta (BAB) effect similar to Black (1972) or Frazzini and Pedersen (2014).

Controlling for the CAPM in Table 3 does not explain much of our strategy returns, which suggests that our results cannot be attributed to BAB. For robustness, Table 7 reports results from a conditional double sort on market beta and MPE. ${ }^{28}$ In each month, stocks are first sorted into quintiles based on the market beta, estimated from one year of daily returns. Then, within each quintile, stocks are further sorted into quintiles based on their MPE. Average excess returns for the 25 resulting portfolios, as well as long stock portfolios with low MPE and short stock portfolios with high MPE within each beta quintile are reported. We observe that the MPE strategies continue to generate significant average returns even after controlling for

\footnotetext{
${ }^{28}$ We thank Nick Roussanov and Marcin Kacperczyk for this suggestion.
} 
market beta. The lowest average return to a long/short MPE portfolio among the five market beta portfolios equals 69 basis points, an estimate that is more than four standard errors above zero. Thus, we conclude that the effect we document is distinct from the betting against the beta effect.

\subsection{Further Robustness Tests}

The cross-sectional return predictability due to MPE is a robust feature of the data. Section B of the Online Appendix shows that the predictability is robust to alternative portfolio construction methods. In fact, using equal-weighting instead of value-weighting, all stock breakpoints instead of NYSE breakpoints, or decile sorting instead of quintile sorting increases the average returns and alphas to the long/short strategies examined in Table 3 . Further, using double sorts, spanning tests, and Fama-MacBeth regressions, Section Cof the Online Appendix shows that the predictive power of MPE survives even after controlling for the underlying characteristics used to construct it. Even after we control for all five characteristics in the spanning tests, the strategy based on the MPE index continues to generate an abnormal return. Similarly, the premium we document is not a different anomaly in disguise. Again, using double sorts, spanning tests, and Fama-MacBeth regressions, Section $\mathrm{D}$ of the Online Appendix shows that MPE's predictability is independent of the 23 anomalies examined in Novy-Marx and Velikov (2016).

Another possible concern about the robustness of our results is the construction of the MPE index. To this end, Section $\mathrm{E}$ of the Online Appendix shows that using a different number of days around the FOMC meetings we use to gauge the firms' reactions does not change the significance of the results. Finally, Section F of the Online Appendix shows that the MPE estimation and the asset pricing tests are robust to using the Bernanke and Kuttner (2005) or the Gürkaynak, Sack, and Swanson (2005) “wide” measures for monetary policy surprises. 


\section{Conclusion}

In this paper, we find that stocks that react more positively to expansionary monetary policy surprises earn lower average returns. A long/short trading strategy designed to exploit this effect achieves an annualized return of 9.96 percent ( $t$-statistic of 5.92), an annualized Sharpe Ratio of 0.93, and a Fama and French (2015) alpha of 5.88 percent ( $t$-statistic 4.39) between 1975 and 2015. Measuring the monetary policy exposure of an individual stock is a difficult identification problem because the idiosyncratic volatility of individual stocks leads to large standard errors of estimates from a direct approach, especially when a stock does not have a long enough history. Instead, in the spirit of the literature on financial constraints and distress, we generate a parsimonious monetary policy exposure index based on observable firm characteristics that are likely to drive the exposure of firms to monetary policy. Therefore, our approach builds a bridge between the literature that connects firm characteristics to expected returns and the literature that studies macroeconomic aggregates as a predictor of asset returns. While we derive our monetary policy exposure index to study its implications for asset pricing, our index can also be useful in future research about the relationship between firms' financing and investment decisions and monetary policy. 


\section{References}

Adrian, Tobias, and Nina Boyarchenko. 2012. "Intermediary leverage cycles and financial stability." Working paper.

Adrian, Tobias, Erkko Etula, and Tyler Muir. 2014. "Financial Intermediaries and the CrossSection of Asset Returns.” The Journal of Finance 69(6): 2557-2596.

Altman, Edward. 1968. "Financial ratios, discriminant analysis and the prediction of corporate bankruptcy." Journal of Finance 23(4): 589-609.

Balduzzi, Pierluigi. 2007. "Money and asset prices in a continuous-time Lucas and Stokey cash-in-advance economy." Journal of Economic Dynamics and Control 31: 2713-2743.

Bansal, Ravi, and Wilbur John Coleman. 1996. “A Monetary Explanation of the Equity Premium, Term Premium, and Risk-Free Rate Puzzles.” Journal of Political Economy 104(6): $1135-1171$.

Bernanke, Ben, and Alan Blinder. 1988. "Credit, Money, and Aggregate Demand." American Economic Review P\&P 78: 435-439.

Bernanke, Ben, and Kenneth Kuttner. 2005. "What explains the stock market's reaction to Federal Reserve policy?" Journal of Finance 60: 1221-1257.

Black, Fisher. 1972. "Capital market equilibrium with restricted borrowing.” Journal of Business 45: 444-455.

Brunnermeier, Marcus, and Lasse H. Pedersen. 2009. "Market liquidity and funding liquidity." Review of Financial Studies 22: 2201-2238.

Brunnermeier, Marcus, and Yuliy Sannikov. 2014. "A macroeconomic model with a financial sector." American Economic Review Forthcoming. 
Buraschi, Andrea, Andrea Carnelli, and Paul Whelan. 2014. "Monetary policy and treasury risk premia." Working paper.

Campbell, Jeffrey R., Charles E. Evans, Jonas D. M. Fisher, and Alejandro Justiniano. 2012. "Macroeconomic Effects of FOMC Forward Guidance." Brookings Papers on Economic Activity 1-80.

Campbell, John Y., Jens Hilscher, and Jan Szilagyi. 2008. "In search of distress risk.” Journal of Finance 63: 2899-2939.

Campbell, John Y., Carolin Pflueger, and Luis M. Viceira. 2015. "Monetary policy drivers of bond and equity risks." Working paper.

Carhart, Mark M. 1997. "On the persistence in mutual fund performance.” Journal of Finance 52: $57-82$.

Chan, K. C., Silverio Foresi, and Larry H. P. Lang. 1996. "Does Money Explain Asset Returns? Theory and Empirical Analysis.” Journal of Finance 51(1): 345-361.

Cochrane, John. 2001. Asset Pricing. New Jersey, USA: Princeton University Press.

Cooper, Michael J., Huseyin Gulen, and Michael J. Schill. 2008. "Asset growth and the crosssection of stock returns." Journal of Finance 63: 1609-1651.

Dechow, Patricia, Richard Sloan, and Mark Soliman. 2004. "Implied equity duration: A new measure of equity risk." Review of Accounting Studies 9: 197-228.

Dichev, Ilia. 1998. "Is the risk of bankruptcy a systemic risk?" Journal of Finance 53: 11311147.

Drechsler, Itamar, Alexi Savov, and Philipp Schnabl. 2015. "A model of monetary policy and risk premia." Journal of Finance Forthcoming. 
Ehrmann, Michael, and Marcel Fratzcher. 2004. "Taking stock: Monetary policy transmission to equity markets." Journal of Money, Credit and Banking 36: 719-738.

Evans, Charles L. 1998. "Real-Time Taylor Rules and the Federal Funds Futures Market." Economic Perspectives - Federal Reserve Bank of Chicago 22(3): 44-55.

Fama, Eugene F., and Kenneth R. French. 1993. "Common risk factors in the returns on stocks and bonds.” Journal of Financial Economics 33: 3-56.

Fama, Eugene F., and Kenneth R. French. 2015. "A five-factor asset pricing model." Journal of Financial Economics 116: 1-22.

Frazzini, Andrea, and Lasse H. Pedersen. 2014. "Betting against beta." Journal of Financial Economics 111: 1-25.

Gao, George, Xiaomeng Lu, Zhaogang Song, and Hongjun Yan. 2016. "Macro-disagreement beta." Working paper.

Geanakopoulos, John. 2009. “The leverage cycle.” NBER Macroeconomics Annual 24: 1-65.

Gertler, Mark, and Simon Gilchrist. 1994. "Monetary policy, business cycles, and the behavior of small manufacturing firms." Quarterly Journal of Economics 109(2): 309-340.

Gomes, Joao, Urban Jermann, and Lukas Schmid. 2016. “Sticky Leverage.” American Economic Review Forthcoming.

Gürkaynak, Refet, Brian Sack, and Eric Swanson. 2005. "Do actions speak louder than words? The response of asset prices to monetary policy actions and statements." International Journal of Central Banking 1(1): 55-93.

Gürkaynak, Refet, Brian Sack, and Eric Swanson. 2007. "Market-based measures of monetary policy expectations.” Journal of Business and Economic Statistics 25: 201-212. 
Harvey, Capmbell, Yan Liu, and Hequng Zhu. 2016. “... and the Cross-Section of Expected Returns." Review of Financial Studies 29(1): 5-68.

He, Zhiguo, and Arvind Krishnamurthy. 2013. "Intermediary asset pricing." American Economic Review 103: 732-760.

Ippolito, Filippo, Ali K. Ozdagli, and Ander Perez. 2015. "The Transmission of Monetary Policy through Bank Lending: The Floating Rate Channel.” Working Paper.

Kaplan, Steven, and Luigi Zingales. 1997. "Do investment-cash flow sensitivities provide useful measures of financing constraints?" Quarterly Journal of Economics 112(1): 169215.

Kuttner, Kenneth. 2001. "Monetary policy surprises and interest rates: Evidence from the Fed funds futures market." Journal of Monetary Economics 47: 523-544.

Lamont, Owen, Christopher Polk, and Jesus Saa-Requejo. 2001. "Financial constraints and stock returns." Review of Financial Studies 14: 529-554.

Lettau, Martin, and Sydney Ludvigson. 2001. "Consumption, aggregate wealth, and expected stock returns." Journal of Finance 56(3): 815-849.

Li, Erica X.N., and Francisco Palomino. 2014. "Nominal rigidities, asset returns, and monetary policy." Journal of Monetary Economics 66: 210-225.

Lioui, Abraham, and Paulo Maio. 2014. "Interest rate risk and the cross-section of stock returns." Journal of Financial and Quantitative Analysis Forthcoming.

Lucas, Robert, and Nancy Stokey. 1987. "Money and interest in a cash-in-advance economy." Econometrica 55(3): 491-513. 
Lucca, David, and Emanuel Moench. 2015. "The pre-FOMC announcement drift." Journal of Finance 70(1): 329-371.

Maio, Paulo. 2014. "Another look at the stock return response to monetary policy actions." Review of Finance 18(1): 1-51.

MSCI. 2010. "The fundamentals of fundamental factor models." MSCI Research Insight.

Nakamura, Emi, and Jon Steinsson. 2015. "High Frequency Identifcation of Monetary NonNeutrality." Working Paper.

Neuhierl, Andreas, and Michael Weber. 2016. "Monetary policy and the stock market: Timeseries evidence." Working paper.

Nissim, D., and S. Penman. 2001. "Ratio analysis and equity valuation: From research to practice." Review of Accounting Studies 6(1): 109-154.

Novy-Marx, Robert. 2013. "The other side of value: The gross profitability premium.” Journal of Financial Economics 108: 1-28.

Novy-Marx, Robert. 2016. "Testing strategies based on multiple signals.” Working paper.

Novy-Marx, Robert, and Mihail Velikov. 2016. "A taxonomy of anomalies and their trading costs." Review of Financial Studies 29(1): 104-147.

Ohlson, James A. 1980. "Financial rations and the probabilistic prediction of bankruptcy." Journal of Accounting Research 18: 109-131.

Ozdagli, Ali. 2015. "Financial frictions and reaction of stock prices to monetary policy shocks." Working paper.

Pastor, Lubos, and Robert Stambaugh. 2003. "Liquidity risk and expected stock returns." Journal of Political Economy 111(3): 642-685. 
Perez-Quiros, Gabriel, and Allan Timmermann. 2000. "Firm size and cyclical variations in stock returns." Journal of Finance 55(3): 1229-1262.

Piazzesi, Monika, and Eric T. Swanson. 2008. "Futures Prices as Risk-Adjusted Forecasts of Monetary Policy.” Journal of Monetary Economics 55(4): 677-691.

Rigobon, Roberto, and Brian Sack. 2004. "The impact of monetary policy on asset prices." Journal of Monetary Economics 51: 1553-1575.

Romer, Christina, and David Romer. 2000. "Federal Reserve Information and the Behavior of Interest Rate." American Economic Review 90(3): 429-457.

Savor, Pavel, and Mungo Wilson. 2013. "How much do investors care about macroeconomic risk? Evidence from scheduled economic announcements." Journal of Financial and Quantitative Analysis 48: 343-375.

Savor, Pavel, and Mungo Wilson. 2014. "Asset pricing: A tale of two days." Journal of Financial Economics 113: 171-201.

Thorbecke, William. 1997. "On stock market returns and monetary policy." Journal of Finance 52: $635-654$.

Uhlig, Harald. 2007. "Explaining asset prices with external habits and wage rigidities in a DSGE model." American Economic Review P\&P 97(2): 239-243.

Velikov, Mihail. 2015. "FOMC announcements and predictable returns." Working paper.

Weber, Michael. 2015. "Nominal rigidities and asset pricing." Working paper.

Weber, Michael. 2016. “The Term Structure of Equity Returns: Risk or Mispricing?” Working paper. 
Whited, Toni, and Guojun Wu. 2006. "Financial constraints risk." Review of Financial Studies 19(2): 531-559. 
Table 1: Monetary Policy Exposure Estimation

This table reports estimates from panel ordinary least square regressions estimated at the FOMC meeting/firm level. Specification (1) follows $r_{i t}^{0,1}=\alpha+\beta M P S_{t}+\varepsilon_{i t}$, Specifications (2)-(7) follow $r_{i t}^{0,1}=\alpha+\sum_{k=1}^{n} \beta_{k} x_{i t}+\sum_{k=1}^{n} \gamma_{k} M P S_{t} \times x_{i t}+$ Controls $_{i t}+\varepsilon_{i t}$, and Specification (8) follows $r_{i t}^{0,1}=\alpha+\beta_{\mathrm{MPE} \mathrm{MPE}_{i t}}+\gamma_{\mathrm{MPE}} M P S_{t} \times \mathrm{MPE}_{i t}+$ Controls $_{i t}+\varepsilon_{i t}$, where $r_{i t}^{0,1}$ is the 2-day cumulative return on stocks surrounding scheduled FOMC meetings (days 0 and 1), MPS $S_{t}$ is the "tight" monetary policy surprise measure developed by Gürkaynak, Sack, and Swanson (2005), multiplied by -1 so that $M P S>0$ is expansionary, $x_{i t}$ are firm characteristics described in Appendix A MPE is monetary policy exposure, estimated using equation (3) from the text, and Controls $i t$ includes meeting, industry, and rating fixed effects, and the interactions of the industry and rating fixed effects with the monetary policy surprises. The regressions are estimated at the meeting-firm level. Independent variables are winsorized at the 1 percent level within each cross-section. The $t$-statistics are in brackets. The sample excludes financial firms, firms with non-traded CRSP closing prices on the day before the meetings, and firms with CRSP closing prices lower than or equal to $\$ 5$ on the meeting days, and it covers 115 scheduled FOMC meetings between 01/1994 and 06/2008.

\begin{tabular}{|c|c|c|c|c|c|c|c|c|}
\hline Var & $\overline{(1)}$ & $(2)$ & (3) & $\overline{(4)}$ & $(5)$ & (6) & (7) & $(8)$ \\
\hline Cash & & $\begin{array}{l}0.22 \\
{[2.65]}\end{array}$ & & & & & $\begin{array}{l}0.28 \\
{[2.91]}\end{array}$ & \\
\hline CF Duration Rank & & & $\begin{array}{l}0.17 \\
{[4.67]}\end{array}$ & & & & $\begin{array}{l}0.20 \\
{[4.78]}\end{array}$ & \\
\hline Whited-Wu Rank & & & & $\begin{array}{l}-0.04 \\
{[-0.82]}\end{array}$ & & & $\begin{array}{l}-0.10 \\
{[-2.02]}\end{array}$ & \\
\hline CF Volatility & & & & & $\begin{array}{l}0.04 \\
{[0.47]}\end{array}$ & & $\begin{array}{l}0.01 \\
{[0.13]}\end{array}$ & \\
\hline Operating Profitability & & & & & & $\begin{array}{l}0.09 \\
{[0.42]}\end{array}$ & $\begin{array}{l}0.31 \\
{[1.27]}\end{array}$ & \\
\hline MPE & & & & & & & & $\begin{array}{l}4.48 \\
{[6.98]}\end{array}$ \\
\hline MPS & $\begin{array}{l}5.39 \\
{[33.54]}\end{array}$ & & & & & & & \\
\hline MPS x Cash & & $\begin{array}{l}-4.45 \\
{[-3.14]}\end{array}$ & & & & & $\begin{array}{l}-4.99 \\
{[-3.05]}\end{array}$ & \\
\hline MPS x CF Duration Rank & & & $\begin{array}{l}3.15 \\
{[4.89]}\end{array}$ & & & & $\begin{array}{l}1.75 \\
{[2.36]}\end{array}$ & \\
\hline MPS x Whited-Wu Rank & & & & $\begin{array}{l}-2.48 \\
{[-2.99]}\end{array}$ & & & $\begin{array}{l}-2.10 \\
{[-2.35]}\end{array}$ & \\
\hline MPS x CF Volatility & & & & & $\begin{array}{l}8.55 \\
{[5.84]}\end{array}$ & & $\begin{array}{l}9.26 \\
{[5.68]}\end{array}$ & \\
\hline MPS x Operating Profitability & & & & & & $\begin{array}{l}-20.93 \\
{[-5.87]}\end{array}$ & $\begin{array}{l}-11.84 \\
{[-2.90]}\end{array}$ & \\
\hline MPS x MPE & & & & & & & & $\begin{array}{l}1.06 \\
{[9.23]}\end{array}$ \\
\hline Meeting FE & No & Yes & Yes & Yes & Yes & Yes & Yes & Yes \\
\hline Industry FE & No & Yes & Yes & Yes & Yes & Yes & Yes & Yes \\
\hline Industry FE $\times$ MPS & No & Yes & Yes & Yes & Yes & Yes & Yes & Yes \\
\hline Rating FE & No & Yes & Yes & Yes & Yes & Yes & Yes & Yes \\
\hline Rating FE $\times$ MPS & No & Yes & Yes & Yes & Yes & Yes & Yes & Yes \\
\hline$n^{n} \bar{R}^{2}(\%)$ & $\begin{array}{l}275,596 \\
0.41\end{array}$ & $\begin{array}{l}357,206 \\
7.52\end{array}$ & $\begin{array}{l}304,704 \\
8.09\end{array}$ & $\begin{array}{l}336,221 \\
7.59\end{array}$ & $\begin{array}{l}287,583 \\
7.89\end{array}$ & $\begin{array}{l}348,652 \\
7.58\end{array}$ & $\begin{array}{l}275,596 \\
8.28\end{array}$ & $\begin{array}{l}274,818 \\
8.32\end{array}$ \\
\hline
\end{tabular}


Table 2: Forward Guidance Table

This table reports regression estimates from panel ordinary least square regressions from the following specification: $r_{i t}^{0,1}=\alpha+\beta \mathrm{MPE}_{i t}+\gamma \mathrm{FGSX}_{t} \times \mathrm{MPE}_{i t}+\mathrm{Controls}_{i t}+\varepsilon_{i t}$, where $r_{i t}^{0,1}$ is the 2-day cumulative return on stocks surrounding scheduled FOMC meetings (days 0 and 1), MPE is monetary policy exposure, estimated using equation (3) from the text, $F G S X_{t}$ is the change in the rate implied from the price of the X-quarter ahead eurodollar futures contract, following Rigobon and Sack (2004) and Gürkaynak, Sack, and Swanson (2005), multiplied by -1 so that $F G S X>0$ is expansionary, and Controls $s_{i t}$ includes meeting, industry, and rating fixed effects, and the interactions of the industry and rating fixed effects with the monetary policy surprises. The regressions are estimated at the FOMC meeting/firm level. Independent variables are winsorized at the 1 percent level within each cross-section. The $t$-statistics are in brackets. The sample excludes financial firms, firms with non-traded CRSP closing prices on the day before the meeting, and firms with CRSP closing prices lower than or equal to $\$ 5$ on the meeting days and it covers 48 scheduled FOMC meetings between 01/2009 and 12/2014.

\begin{tabular}{|c|c|c|c|c|c|c|c|c|}
\hline Var & (1) & (2) & (3) & (4) & (5) & (6) & (7) & (8) \\
\hline MPE & $\begin{array}{l}-0.00 \\
{[-0.37]}\end{array}$ & $\begin{array}{l}-0.01 \\
{[-0.60]}\end{array}$ & $\begin{array}{l}-0.01 \\
{[-0.76]}\end{array}$ & $\begin{array}{l}-0.01 \\
{[-0.78]}\end{array}$ & $\begin{array}{l}-0.01 \\
{[-0.90]}\end{array}$ & $\begin{array}{l}-0.01 \\
{[-0.96]}\end{array}$ & $\begin{array}{l}-0.01 \\
{[-0.83]}\end{array}$ & $\begin{array}{l}-0.01 \\
{[-0.80]}\end{array}$ \\
\hline FGS1 x MPE & $\begin{array}{l}0.44 \\
{[0.75]}\end{array}$ & & & & & & & \\
\hline FGS2 x MPE & & $\begin{array}{l}0.46 \\
{[1.18]}\end{array}$ & & & & & & \\
\hline FGS3 x MPE & & & $\begin{array}{l}0.55 \\
{[1.84]}\end{array}$ & & & & & \\
\hline FGS4 x MPE & & & & $\begin{array}{l}0.62 \\
{[2.55]}\end{array}$ & & & & \\
\hline FGS5 x MPE & & & & & $\begin{array}{l}0.80 \\
{[3.83]}\end{array}$ & & & \\
\hline FGS6 x MPE & & & & & & $\begin{array}{l}0.92 \\
{[4.87]}\end{array}$ & & \\
\hline FGS7 x MPE & & & & & & & $\begin{array}{l}0.99 \\
{[5.93]}\end{array}$ & \\
\hline FGS8 x MPE & & & & & & & & $\begin{array}{l}0.97 \\
{[6.48]}\end{array}$ \\
\hline Meeting FE & Yes & Yes & Yes & Yes & Yes & Yes & Yes & Yes \\
\hline Industry FE & Yes & Yes & Yes & Yes & Yes & Yes & Yes & Yes \\
\hline Industry FE $\times$ FGSX & Yes & Yes & Yes & Yes & Yes & Yes & Yes & Yes \\
\hline Rating FE & Yes & Yes & Yes & Yes & Yes & Yes & Yes & Yes \\
\hline Rating FE $\times$ FGSX & Yes & Yes & Yes & Yes & Yes & Yes & Yes & Yes \\
\hline$n$ & 90,092 & 90,092 & 90,092 & 90,092 & 90,092 & 90,092 & 90,092 & 90,092 \\
\hline $\bar{R}^{2}(\%)$ & 27.04 & 27.06 & 27.03 & 27.03 & 27.01 & 26.99 & 26.98 & 26.98 \\
\hline
\end{tabular}


Table 3: Full-Sample Portfolio Performance

This table reports average excess returns, alphas, and loadings on the Fama and French (2015) five-factor model. In each month, firms are sorted by their monetary policy exposure (MPE) into quintiles based on NYSE breakpoints. MPE is estimated using equation (3) from the text. For each of the five portfolios, and for a portfolio long stocks with low MPE and short stocks with high MPE, average value-weighted returns in excess of the risk-free rate and alphas with respect to the CAPM, Fama and French (1993) three-factor model, Fama and French (1993) three-factor model augmented with the Carhart (1997) momentum factor, and the Fama and French (2015) five-factor model are reported in Panel A. Panel B reports the loadings for the six portfolios on the Fama and French (2015) five-factor model. The $t$-statistics are in brackets. The sample period is $01 / 1975$ to $12 / 2015$.

\begin{tabular}{|c|c|c|c|c|c|c|}
\hline \multicolumn{7}{|c|}{ Panel A: Excess returns and alphas on MPE-sorted portfolios } \\
\hline & (L) & $(2)$ & (3) & (4) & $(\mathrm{H})$ & $(\mathrm{L}-\mathrm{H})$ \\
\hline$r^{e}$ & $\begin{array}{l}1.33 \\
{[5.54]}\end{array}$ & $\begin{array}{l}1.00 \\
{[4.58]}\end{array}$ & $\begin{array}{l}0.80 \\
{[4.21]}\end{array}$ & $\begin{array}{l}0.65 \\
{[3.26]}\end{array}$ & $\begin{array}{l}0.50 \\
{[2.37]}\end{array}$ & $\begin{array}{l}0.83 \\
{[5.92]}\end{array}$ \\
\hline$\alpha^{\mathrm{CAPM}}$ & $\begin{array}{l}0.65 \\
{[5.73]}\end{array}$ & $\begin{array}{l}0.35 \\
{[4.24]}\end{array}$ & $\begin{array}{l}0.24 \\
{[3.23]}\end{array}$ & $\begin{array}{l}0.04 \\
{[0.70]}\end{array}$ & $\begin{array}{l}-0.15 \\
{[-2.62]}\end{array}$ & $\begin{array}{l}0.80 \\
{[5.66]}\end{array}$ \\
\hline$\alpha^{\mathrm{FF} 3}$ & $\begin{array}{l}0.48 \\
{[5.22]}\end{array}$ & $\begin{array}{l}0.22 \\
{[2.93]}\end{array}$ & $\begin{array}{l}0.14 \\
{[2.09]}\end{array}$ & $\begin{array}{l}0.04 \\
{[0.59]}\end{array}$ & $\begin{array}{l}-0.03 \\
{[-0.59]}\end{array}$ & $\begin{array}{l}0.51 \\
{[4.65]}\end{array}$ \\
\hline$\alpha^{\mathrm{FF} 3+\mathrm{UMD}}$ & $\begin{array}{l}0.62 \\
{[7.05]}\end{array}$ & $\begin{array}{l}0.29 \\
{[3.91]}\end{array}$ & $\begin{array}{l}0.16 \\
{[2.34]}\end{array}$ & $\begin{array}{l}0.02 \\
{[0.24]}\end{array}$ & $\begin{array}{l}-0.04 \\
{[-0.80]}\end{array}$ & $\begin{array}{l}0.66 \\
{[6.23]}\end{array}$ \\
\hline$\alpha^{\mathrm{FF} 5}$ & $\begin{array}{l}0.44 \\
{[4.70]}\end{array}$ & $\begin{array}{l}0.14 \\
{[1.82]}\end{array}$ & $\begin{array}{l}0.04 \\
{[0.54]}\end{array}$ & $\begin{array}{l}-0.09 \\
{[-1.49]}\end{array}$ & $\begin{array}{l}-0.05 \\
{[-1.04]}\end{array}$ & $\begin{array}{l}0.49 \\
{[4.39]}\end{array}$ \\
\hline \multicolumn{7}{|c|}{ Panel B: Loadings on Fama and French $(2015)$ 5-factor model of MPE-sorted portfolio } \\
\hline & (L) & $(2)$ & (3) & (4) & $(\mathrm{H})$ & $(\mathrm{L}-\mathrm{H})$ \\
\hline$\beta_{\text {MKT }}$ & $\begin{array}{l}1.02 \\
{[45.94]}\end{array}$ & $\begin{array}{l}1.04 \\
{[57.53]}\end{array}$ & $\begin{array}{l}0.96 \\
{[58.65]}\end{array}$ & $\begin{array}{l}1.00 \\
{[66.83]}\end{array}$ & $\begin{array}{l}0.98 \\
{[82.88]}\end{array}$ & $\begin{array}{l}0.05 \\
{[1.84]}\end{array}$ \\
\hline$\beta_{\mathrm{SMB}}$ & $\begin{array}{l}0.55 \\
{[16.43]}\end{array}$ & $\begin{array}{l}0.24 \\
{[8.90]}\end{array}$ & $\begin{array}{l}0.03 \\
{[1.11]}\end{array}$ & $\begin{array}{l}-0.04 \\
{[-1.80]}\end{array}$ & $\begin{array}{l}-0.08 \\
{[-4.47]}\end{array}$ & $\begin{array}{l}0.63 \\
{[15.71]}\end{array}$ \\
\hline$\beta_{\mathrm{HML}}$ & $\begin{array}{l}0.17 \\
{[3.97]}\end{array}$ & $\begin{array}{l}0.14 \\
{[4.08]}\end{array}$ & $\begin{array}{l}0.15 \\
{[4.65]}\end{array}$ & $\begin{array}{l}-0.07 \\
{[-2.40]}\end{array}$ & $\begin{array}{l}-0.26 \\
{[-11.28]}\end{array}$ & $\begin{array}{l}0.43 \\
{[8.29]}\end{array}$ \\
\hline$\beta_{\text {RMW }}$ & $\begin{array}{l}0.11 \\
{[2.43]}\end{array}$ & $\begin{array}{l}0.12 \\
{[3.25]}\end{array}$ & $\begin{array}{l}0.16 \\
{[4.74]}\end{array}$ & $\begin{array}{l}0.18 \\
{[5.93]}\end{array}$ & $\begin{array}{l}0.05 \\
{[2.15]}\end{array}$ & $\begin{array}{l}0.06 \\
{[1.08]}\end{array}$ \\
\hline$\beta_{\mathrm{CMA}}$ & $\begin{array}{l}0.01 \\
{[0.13]}\end{array}$ & $\begin{array}{l}0.16 \\
{[3.04]}\end{array}$ & $\begin{array}{l}0.18 \\
{[3.60]}\end{array}$ & $\begin{array}{l}0.25 \\
{[5.67]}\end{array}$ & $\begin{array}{l}-0.00 \\
{[-0.02]}\end{array}$ & $\begin{array}{l}0.01 \\
{[0.12]}\end{array}$ \\
\hline
\end{tabular}


Table 4: Fama-MacBeth Regressions

The table documents results from Fama-MacBeth regressions of the form $r_{t j}=\beta^{\prime} \mathbf{x}_{t-1, j}+\varepsilon_{t j}$. The characteristics $\mathbf{x}_{t-1, j}$ include monetary policy exposure (MPE), the $\log$ of market capitalization $(\log (\mathrm{ME}))$, the $\log$ of the book-to-market ratio $(\log (\mathrm{BM}))$, gross profitability (GP/A), investment (I/A), momentum $\left(r_{12,1}\right)$, and short-term reversals $\left(r_{1,0}\right)$. MPE is estimated using equation (3) from the text. GP/A follows Novy-Marx (2013). I/A follows Cooper, Gulen, and Schill (2008). Independendent variables are winsorized at the 1 percent level. The $t$-statistics are in brackets. The sample period is 01/1975 to 12/2015.

\begin{tabular}{|c|c|c|c|c|c|c|c|c|c|}
\hline \multicolumn{10}{|c|}{ Regressions of the form $r_{t j}=\beta^{\prime} \mathbf{x}_{t-1, j}+\varepsilon_{t j}$} \\
\hline Coef. & (1) & (2) & (3) & (4) & $(5)$ & (6) & (7) & (8) & (9) \\
\hline MPE & $\begin{array}{l}-33.46 \\
{[-12.99]}\end{array}$ & $\begin{array}{l}-31.63 \\
{[-8.95]}\end{array}$ & $\begin{array}{l}-33.03 \\
{[-13.39]}\end{array}$ & $\begin{array}{l}-32.97 \\
{[-12.54]}\end{array}$ & $\begin{array}{l}-30.56 \\
{[-12.25]}\end{array}$ & $\begin{array}{l}-34.10 \\
{[-14.28]}\end{array}$ & $\begin{array}{l}-33.27 \\
{[-13.28]}\end{array}$ & & $\begin{array}{l}-30.55 \\
{[-11.76]}\end{array}$ \\
\hline $\log (\mathrm{ME})$ & & $\begin{array}{l}-0.07 \\
{[-1.35]}\end{array}$ & & & & & & $\begin{array}{l}-0.12 \\
{[-2.73]}\end{array}$ & $\begin{array}{l}-0.05 \\
{[-1.05]}\end{array}$ \\
\hline $\log (\mathrm{B} / \mathrm{M})$ & & & $\begin{array}{l}0.08 \\
{[1.07]}\end{array}$ & & & & & $\begin{array}{l}0.25 \\
{[3.75]}\end{array}$ & $\begin{array}{l}-0.02 \\
{[-0.25]}\end{array}$ \\
\hline GP/A & & & & $\begin{array}{l}-0.02 \\
{[-0.12]}\end{array}$ & & & & $\begin{array}{l}0.65 \\
{[4.53]}\end{array}$ & $\begin{array}{l}-0.03 \\
{[-0.23]}\end{array}$ \\
\hline $\mathrm{I} / \mathrm{A}$ & & & & & $\begin{array}{l}-0.77 \\
{[-5.56]}\end{array}$ & & & $\begin{array}{l}-0.77 \\
{[-9.30]}\end{array}$ & $\begin{array}{l}-0.62 \\
{[-6.56]}\end{array}$ \\
\hline$r_{12,1}$ & & & & & & $\begin{array}{l}0.49 \\
{[2.50]}\end{array}$ & & $\begin{array}{l}0.32 \\
{[1.79]}\end{array}$ & $\begin{array}{l}0.45 \\
{[2.58]}\end{array}$ \\
\hline$r_{1,0}$ & & & & & & & $\begin{array}{l}-4.64 \\
{[-9.25]}\end{array}$ & $\begin{array}{l}-5.37 \\
{[-12.63]}\end{array}$ & $\begin{array}{l}-5.36 \\
{[-12.79]}\end{array}$ \\
\hline
\end{tabular}


Table 5: Out-of-Sample Portfolio Performance

This table reports average excess returns, alphas, and loadings on the Fama and French (2015) five-factor model. In each month, firms are sorted by their monetary policy exposure (MPE) into quintiles based on NYSE breakpoints. MPE is estimated similar to equation (3) from the text, but using coefficients from regressions using only historically available information for meetings starting in 02/1994 and ending before the end of the portfolio formation month. The first MPE estimation uses 20 scheduled FOMC meetings between 02/1994 and 07/1996. For months beyond 07/2008, all 115 scheduled FOMC meetings between 02/1994 and 06/2008 are used. For each of the five portfolios, and for a portfolio long stocks with low MPE and short stocks with high MPE, average value-weighted returns in excess of the risk-free rate and alphas with respect to the CAPM, Fama and French (1993) three-factor model, Fama and French (1993) three-factor model augmented with the Carhart (1997) momentum factor, and the Fama and French (2015) five-factor model are reported in Panel A. Panel B reports the loadings for the six portfolios on the Fama and French (2015) five-factor model. The $t$-statistics are in brackets. The sample period is $08 / 1996$ to $12 / 2015$.

\begin{tabular}{|c|c|c|c|c|c|c|}
\hline \multicolumn{7}{|c|}{ Panel A: Excess returns and alphas on MPE-sorted portfolios } \\
\hline & $(\mathrm{L})$ & $(2)$ & (3) & (4) & $(\mathrm{H})$ & $(\mathrm{L}-\mathrm{H})$ \\
\hline$r^{e}$ & $\begin{array}{l}1.28 \\
{[3.60]}\end{array}$ & $\begin{array}{l}0.98 \\
{[3.17]}\end{array}$ & $\begin{array}{l}0.97 \\
{[3.38]}\end{array}$ & $\begin{array}{l}0.63 \\
{[2.17]}\end{array}$ & $\begin{array}{l}0.52 \\
{[1.65]}\end{array}$ & $\begin{array}{l}0.76 \\
{[3.11]}\end{array}$ \\
\hline$\alpha^{\mathrm{CAPM}}$ & $\begin{array}{l}0.71 \\
{[3.62]}\end{array}$ & $\begin{array}{l}0.45 \\
{[3.35]}\end{array}$ & $\begin{array}{l}0.48 \\
{[3.72]}\end{array}$ & $\begin{array}{l}0.11 \\
{[1.13]}\end{array}$ & $\begin{array}{l}-0.05 \\
{[-0.55]}\end{array}$ & $\begin{array}{l}0.77 \\
{[3.12]}\end{array}$ \\
\hline$\alpha^{\mathrm{FF} 3}$ & $\begin{array}{l}0.55 \\
{[4.01]}\end{array}$ & $\begin{array}{l}0.31 \\
{[3.21]}\end{array}$ & $\begin{array}{l}0.39 \\
{[3.48]}\end{array}$ & $\begin{array}{l}0.09 \\
{[0.92]}\end{array}$ & $\begin{array}{l}0.04 \\
{[0.61]}\end{array}$ & $\begin{array}{l}0.51 \\
{[3.20]}\end{array}$ \\
\hline$\alpha^{\mathrm{FF} 3+\mathrm{UMD}}$ & $\begin{array}{l}0.63 \\
{[4.68]}\end{array}$ & $\begin{array}{l}0.34 \\
{[3.48]}\end{array}$ & $\begin{array}{l}0.40 \\
{[3.52]}\end{array}$ & $\begin{array}{l}0.07 \\
{[0.73]}\end{array}$ & $\begin{array}{l}0.04 \\
{[0.60]}\end{array}$ & $\begin{array}{l}0.59 \\
{[3.74]}\end{array}$ \\
\hline$\alpha^{\mathrm{FF5}}$ & $\begin{array}{l}0.51 \\
{[3.59]}\end{array}$ & $\begin{array}{l}0.29 \\
{[2.87]}\end{array}$ & $\begin{array}{l}0.24 \\
{[2.09]}\end{array}$ & $\begin{array}{l}-0.09 \\
{[-0.96]}\end{array}$ & $\begin{array}{l}0.03 \\
{[0.46]}\end{array}$ & $\begin{array}{l}0.48 \\
{[2.92]}\end{array}$ \\
\hline \multicolumn{7}{|c|}{ Panel B: Loadings on Fama and French $(2015)$ 5-factor model of MPE-sorted portfolios } \\
\hline$\beta_{\mathrm{MKT}}$ & $\begin{array}{l}0.95 \\
{[26.83]}\end{array}$ & $\begin{array}{l}0.95 \\
{[38.25]}\end{array}$ & $\begin{array}{l}0.95 \\
{[34.30]}\end{array}$ & $\begin{array}{l}1.00 \\
{[44.88]}\end{array}$ & $\begin{array}{l}0.96 \\
{[54.62]}\end{array}$ & $\begin{array}{l}-0.01 \\
{[-0.35]}\end{array}$ \\
\hline$\beta_{\mathrm{SMB}}$ & $\begin{array}{l}0.64 \\
{[13.13]}\end{array}$ & $\begin{array}{l}0.29 \\
{[8.56]}\end{array}$ & $\begin{array}{l}0.12 \\
{[3.19]}\end{array}$ & $\begin{array}{l}-0.01 \\
{[-0.36]}\end{array}$ & $\begin{array}{l}-0.06 \\
{[-2.37]}\end{array}$ & $\begin{array}{l}0.69 \\
{[12.44]}\end{array}$ \\
\hline$\beta_{\mathrm{HML}}$ & $\begin{array}{l}0.25 \\
{[3.97]}\end{array}$ & $\begin{array}{l}0.35 \\
{[7.89]}\end{array}$ & $\begin{array}{l}0.15 \\
{[2.94]}\end{array}$ & $\begin{array}{l}-0.10 \\
{[-2.57]}\end{array}$ & $\begin{array}{l}-0.30 \\
{[-9.42]}\end{array}$ & $\begin{array}{l}0.55 \\
{[7.53]}\end{array}$ \\
\hline$\beta_{\text {RMW }}$ & $\begin{array}{l}0.03 \\
{[0.47]}\end{array}$ & $\begin{array}{l}0.03 \\
{[0.67]}\end{array}$ & $\begin{array}{l}0.22 \\
{[3.99]}\end{array}$ & $\begin{array}{l}0.19 \\
{[4.15]}\end{array}$ & $\begin{array}{l}0.07 \\
{[1.87]}\end{array}$ & $\begin{array}{l}-0.03 \\
{[-0.40]}\end{array}$ \\
\hline$\beta_{\mathrm{CMA}}$ & $\begin{array}{l}0.10 \\
{[1.12]}\end{array}$ & $\begin{array}{l}0.03 \\
{[0.55]}\end{array}$ & $\begin{array}{l}0.21 \\
{[3.11]}\end{array}$ & $\begin{array}{l}0.36 \\
{[6.46]}\end{array}$ & $\begin{array}{l}-0.08 \\
{[-1.85]}\end{array}$ & $\begin{array}{l}0.18 \\
{[1.78]}\end{array}$ \\
\hline
\end{tabular}


Table 6: Excluding FOMC Meetings

This table reports average excess returns, alphas, and loadings on the Fama and French (2015) five-factor model. In each month, firms are sorted by their monetary policy exposure (MPE) into quintiles based on NYSE breakpoints. MPE is estimated using equation (3) from the text. For each of the five portfolios, and for a portfolio long stocks with low MPE and short stocks with high MPE, average value-weighted returns in excess of the risk-free rate and alphas with respect to the CAPM, Fama and French (1993) three-factor model, Fama and French (1993) three-factor model augmented with the Carhart (1997) momentum factor, and the Fama and French (2015) five-factor model are reported in Panel A. Panel B reports the loadings for the six portfolios on the Fama and French (2015) five-factor model. The returns to the portfolios are estimated by excluding the two-day (days -1 and 0 ) daily returns around 339 days with scheduled or unscheduled FOMC meetings between 01/1975 and 12/2015 from the monthly returns. The $t$-statistics are in brackets. The sample period is $01 / 1975$ to $12 / 2015$.

\begin{tabular}{|c|c|c|c|c|c|c|}
\hline \multicolumn{7}{|c|}{ Panel A: Excess returns and alphas on MPE-sorted portfolios } \\
\hline & $(\mathrm{L})$ & $(2)$ & (3) & (4) & $(\mathrm{H})$ & $(\mathrm{L}-\mathrm{H})$ \\
\hline$r^{e}$ & $\begin{array}{l}1.15 \\
{[4.94]}\end{array}$ & $\begin{array}{l}0.80 \\
{[3.80]}\end{array}$ & $\begin{array}{l}0.61 \\
{[3.26]}\end{array}$ & $\begin{array}{l}0.43 \\
{[2.22]}\end{array}$ & $\begin{array}{l}0.31 \\
{[1.50]}\end{array}$ & $\begin{array}{l}0.84 \\
{[6.23]}\end{array}$ \\
\hline$\alpha^{\mathrm{CAPM}}$ & $\begin{array}{l}0.51 \\
{[4.23]}\end{array}$ & $\begin{array}{l}0.19 \\
{[2.08]}\end{array}$ & $\begin{array}{l}0.07 \\
{[0.88]}\end{array}$ & $\begin{array}{l}-0.14 \\
{[-1.85]}\end{array}$ & $\begin{array}{l}-0.31 \\
{[-4.18]}\end{array}$ & $\begin{array}{l}0.82 \\
{[5.99]}\end{array}$ \\
\hline$\alpha^{\mathrm{FF} 3}$ & $\begin{array}{l}0.34 \\
{[3.28]}\end{array}$ & $\begin{array}{l}0.06 \\
{[0.67]}\end{array}$ & $\begin{array}{l}-0.02 \\
{[-0.31]}\end{array}$ & $\begin{array}{l}-0.16 \\
{[-2.07]}\end{array}$ & $\begin{array}{l}-0.21 \\
{[-2.98]}\end{array}$ & $\begin{array}{l}0.55 \\
{[5.07]}\end{array}$ \\
\hline$\alpha^{\mathrm{FF} 3+\mathrm{UMD}}$ & $\begin{array}{l}0.46 \\
{[4.46]}\end{array}$ & $\begin{array}{l}0.12 \\
{[1.33]}\end{array}$ & $\begin{array}{l}-0.02 \\
{[-0.25]}\end{array}$ & $\begin{array}{l}-0.19 \\
{[-2.47]}\end{array}$ & $\begin{array}{l}-0.23 \\
{[-3.23]}\end{array}$ & $\begin{array}{l}0.68 \\
{[6.51]}\end{array}$ \\
\hline$\alpha^{\mathrm{FF5}}$ & $\begin{array}{l}0.29 \\
{[2.70]}\end{array}$ & $\begin{array}{l}-0.03 \\
{[-0.34]}\end{array}$ & $\begin{array}{l}-0.14 \\
{[-1.72]}\end{array}$ & $\begin{array}{l}-0.28 \\
{[-3.72]}\end{array}$ & $\begin{array}{l}-0.23 \\
{[-3.22]}\end{array}$ & $\begin{array}{l}0.52 \\
{[4.68]}\end{array}$ \\
\hline \multicolumn{7}{|c|}{ Panel B: Loadings on $\overline{\text { Fama and French }}(\overline{2015})$ 5-factor model of MPE-sorted portfolios } \\
\hline & $(\mathrm{L})$ & $(2)$ & $(3)$ & (4) & $(\mathrm{H})$ & $(\mathrm{L}-\mathrm{H})$ \\
\hline$\beta_{\mathrm{MKT}}$ & $\begin{array}{l}0.98 \\
{[38.69]}\end{array}$ & $\begin{array}{l}0.99 \\
{[47.51]}\end{array}$ & $\begin{array}{l}0.92 \\
{[47.40]}\end{array}$ & $\begin{array}{l}0.95 \\
{[52.10]}\end{array}$ & $\begin{array}{l}0.94 \\
{[54.57]}\end{array}$ & $\begin{array}{l}0.04 \\
{[1.57]}\end{array}$ \\
\hline$\beta_{\mathrm{SMB}}$ & $\begin{array}{l}0.52 \\
{[13.61]}\end{array}$ & $\begin{array}{l}0.22 \\
{[7.08]}\end{array}$ & $\begin{array}{l}0.02 \\
{[0.80]}\end{array}$ & $\begin{array}{l}-0.05 \\
{[-1.84]}\end{array}$ & $\begin{array}{l}-0.08 \\
{[-3.10]}\end{array}$ & $\begin{array}{l}0.59 \\
{[15.07]}\end{array}$ \\
\hline$\beta_{\mathrm{HML}}$ & $\begin{array}{l}0.18 \\
{[3.55]}\end{array}$ & $\begin{array}{l}0.16 \\
{[3.83]}\end{array}$ & $\begin{array}{l}0.16 \\
{[4.17]}\end{array}$ & $\begin{array}{l}-0.04 \\
{[-1.06]}\end{array}$ & $\begin{array}{l}-0.21 \\
{[-6.20]}\end{array}$ & $\begin{array}{l}0.38 \\
{[7.44]}\end{array}$ \\
\hline$\beta_{\mathrm{RMW}}$ & $\begin{array}{l}0.13 \\
{[2.54]}\end{array}$ & $\begin{array}{l}0.13 \\
{[3.02]}\end{array}$ & $\begin{array}{l}0.18 \\
{[4.57]}\end{array}$ & $\begin{array}{l}0.18 \\
{[4.87]}\end{array}$ & $\begin{array}{l}0.05 \\
{[1.55]}\end{array}$ & $\begin{array}{l}0.08 \\
{[1.42]}\end{array}$ \\
\hline$\beta_{\mathrm{CMA}}$ & $\begin{array}{l}0.04 \\
{[0.49]}\end{array}$ & $\begin{array}{l}0.18 \\
{[2.81]}\end{array}$ & $\begin{array}{l}0.18 \\
{[3.13]}\end{array}$ & $\begin{array}{l}0.23 \\
{[4.29]}\end{array}$ & $\begin{array}{l}0.00 \\
{[0.02]}\end{array}$ & $\begin{array}{l}0.04 \\
{[0.45]}\end{array}$ \\
\hline
\end{tabular}


Table 7: Conditional Double Sort on Beta and MPE

This table reports average excess returns to 25 portfolios contructed by a conditional double sort on CAPM beta and monetary policy exposure (MPE). In each month, firms are sorted by their CAPM beta into quintiles. Then, within each quintile, stocks are further sorted into quintiles based on MPE. Average returns to the 25 resulting portfolios, as well as average excess returns on five MPE strategies are reported. The MPE strategies are constructed within each beta quintile, going long stocks with low MPE and short stocks with high MPE. Monetary policy exposure is estimated using equation (3) from the text. CAPM betas are estimated using rolling one year of daily returns. The $t$-statistics are in brackets. The sample period is $01 / 1975$ to $12 / 2015$.

\begin{tabular}{|c|c|c|c|c|c|c|c|}
\hline & & & & $\overline{\mathrm{MPE} Q}$ & & & \\
\hline & & (L) & (2) & (3) & (4) & $(\mathrm{H})$ & $(\mathrm{L}-\mathrm{H})$ \\
\hline & (L) & 1.57 & 1.04 & 0.83 & 0.61 & 0.37 & $\begin{array}{l}1.20 \\
{[5.08]}\end{array}$ \\
\hline$\stackrel{\mathscr{Q}}{\Xi}$ & (2) & 1.31 & 0.90 & 0.92 & 0.75 & 0.53 & $\begin{array}{l}0.78 \\
{[4.57]}\end{array}$ \\
\hline 竞 & (3) & 1.21 & 1.06 & 0.91 & 0.71 & 0.52 & $\begin{array}{l}0.69 \\
{[4.06]}\end{array}$ \\
\hline$\ddot{\infty}$ & (4) & 1.68 & 1.09 & 0.80 & 0.70 & 0.43 & $\begin{array}{l}1.25 \\
{[6.45]}\end{array}$ \\
\hline & (H) & 1.51 & 0.94 & 0.72 & 0.65 & 0.47 & $\begin{array}{l}1.03 \\
{[4.31]}\end{array}$ \\
\hline
\end{tabular}




\section{Appendix A Variable Definitions}

- Cash - Cash and short-term investments (CHEQ) scaled by by the sum of total liabilities (LTQ) and market capitalization

- Cash-Flow Duration Rank - Cash-flow duration rank, estimated using the cash-flow duration measure of Dechow, Sloan, and Soliman (2004):

$$
\text { CF Duration }_{t}=\frac{\Sigma_{s=1}^{T} s \times \mathrm{CF}_{t+s} /(1+r)^{t}}{P_{t}}+T+\frac{1+r}{r} \times \frac{P_{t}-\Sigma_{s=1}^{T} \mathrm{CF}_{t+s} /(1+r)^{s}}{P_{t}} .
$$

Cash flows are measured assuming clean surplus accounting:

$$
\begin{aligned}
\mathrm{CF}_{t} & =\mathrm{E}_{t}-\left(\mathrm{BV}_{t}-\mathrm{BV}_{t-1}\right) \\
& =\mathrm{BV}_{t-1} \times[\underbrace{\frac{\mathrm{E}_{t}}{\mathrm{BV}_{t-1}}}_{\text {ROE }}-\underbrace{\frac{\left(\mathrm{BV}_{t}-\mathrm{BV}_{t-1}\right)}{\mathrm{BV}_{t-1}}}_{\text {Growth in BE }}]
\end{aligned}
$$

and forecasted following Nissim and Penman (2001). ROE follows a first-order autoregressive process with an autocorrelation coefficient equal to the long-run average rate of mean reversion in ROE and a long-run mean equal to the cost of equity. Nissim and Penman (2001) show that past sales growth is a better predictor of future equity growth, so the growth in book equity similarly follows a first-order autoregressive process with an autocorrelation coefficient equal to the long-run average rate of mean reversion in sales growth and a mean equal to the long-run GDP growth rate. Following Dechow, Sloan, and Soliman (2004) and Nissim and Penman (2001), the autocorrelation coefficients for ROE and Sales growth used are 0.57 and 0.24 , respectively, the long-run cost of equity is assumed to be 12 percent, the long-run growth in GDP is assumed to be 6 percent, and the terminal period $T$ is assumed to be 10 years. Instead of the cash-flow duration 
estimate, its percentile rank within each cross-section is used.

- Whited-Wu Rank - Financial constraints index rank, estimated following Whited and Wu (2006). The index is calculated as:

$$
\begin{aligned}
\mathrm{WW}_{i, t}=-0.091 \times \mathrm{CF}_{i, t} & -0.062 \times \mathrm{DIVPOS}_{i, t}+0.021 \times \mathrm{TLTD}_{i, t}-0.044 \times \mathrm{LNTA}_{i, t} \\
& +0.102 \times \mathrm{ISG}_{i, t}-0.035 \times \mathrm{SG}_{i, t},
\end{aligned}
$$

where $\mathrm{CF}$ is the ratio of cash flow to total assets, DIVPOS is the cash dividend indicator variable, TLTD is the ratio of long-term debt to total assets, LNTA is the log of total assets, ISG is the firms' three-digit industry growth, and SG is sales growth. The variables use the most recent COMPUSTAT quarterly observations. Instead of the Whited-Wu index estimate, its percentile rank within each monthly cross-section is used.

- Cash-Flow Volatility - Standard deviation over the last 20 quarters of cash flows, measured by operating cash flow scaled by total assets. Operating cash flow is measured by sales (SALEQ) minus the cost of goods sold (COGSQ) minus selling, administrative, and general expenses (XSGAQ) minus working-capital change (WCAPQ minus lagged WCAPQ). A minimum of eight consecutive quarters is required.

- Operating Profitability - Sales (SALEQ) minus cost of goods sold (COGSQ), scaled by the market value of assets. The market value of assets equals total assets (ATQ) minus shareholder equity (SEQQ) plus market capitalization. 


\section{Appendix B Robustness to Strategy Construction}

This section shows that the cross-sectional return predictability of monetary policy exposure (MPE) in the time-series portfolio tests is not sensitive to the choice of portfolio construction. Table B.1 reports excess returns and alphas with respect to factor models on portfolio sorts on MPE, analogous to the ones in Panel A of Table 3, with different portfolio construction strategies. Panel A of Table B.1 reports results for value-weighted portfolios, constructed using a quintile sort of all stocks to determine the breakpoints instead of breakpoints based on only NYSE stocks. We observe that the long/short portfolio achieves average monthly returns of almost 1 percent, with a highly significant $t$-statistic of 6.44. Even after controlling for the Fama and French (2015) five factors, we are left with an alpha of 0.63 percent per month with a $t$-statistic of 5.35. The fact that the results are stronger in Table B.1 than in Table 3 is not surprising. Using NYSE breakpoints ensures that there are an equal number of NYSE stocks in each portfolio. Since NYSE stocks tend to be those of larger firms, using all stocks for breakpoints can result in relatively fewer large-capitalization stocks in the extreme portfolios, which tends to make the results stronger, even when using value-weighting.

Similarly, Panel B contains results from a quintile sort using NYSE breakpoints, but with equal-weighted porfolios. We observe that the average returns to the long/short portfolio are even stronger, at 1.20 percent per month, with an even bigger $t$-statistic of 10.47. As NovyMarx and Velikov (2016) note, however, equal-weighting tends to produce stronger results due to the influence of micro- and small-capitalization stocks, which tend to be less liquid and more expensive to trade; this is the reason we employ value-weighting throughout this study.

Finally, Panel $\mathrm{C}$ shows that a more-extreme sort also results in stronger performance. The long/short portfolio on a decile strategy using value-weighted portfolio returns and NYSE breakpoints earns a little over 1 percent per month on average, with a $t$-statistic of 6.50 . Even after controlling for the Fama and French (2015) five factors, we are left with an alpha of 0.63 
percent per month, with an associated $t$-statistic of 4.86 .

Table B.1: Robustness to Strategy Construction

This table reports average excess returns and alphas with respect to factor models on portfolio sorts on MPE, similar to the ones in Table 3, Panel A. In each month, firms are sorted by their monetary policy exposure (MPE). MPE is estimated using equation (3) from the text. Average returns in excess of the risk-free rate and alphas with respect to the CAPM, the Fama and French (1993) three-factor model, the Fama and French (1993) three-factor model augmented with the Carhart (1997) momentum factor, and the Fama and French (2015) five-factor model are reported for each portfolio and for a portfolio long stocks with low MPE and short stocks with high MPE. Panel A reports results using value-weighted portfolios, constructed from a quintile sort with all stock breakpoints. Panel B reports results using equal-weighted portfolios, constructed from a quintile sort with NYSE breakpoints. Panel C reports results using valueweighted portfolios, constructed from a decile sort with NYSE breakpoints. The $t$-statistics are in brackets. The sample period is $01 / 1975$ to $12 / 2015$.

\begin{tabular}{|c|c|c|c|c|c|c|}
\hline \multicolumn{7}{|c|}{ Panel A: Quintile sort, value-weighted, all breaks } \\
\hline & (L) & (2) & (3) & (4) & $(\mathrm{H})$ & $(\mathrm{L}-\mathrm{H})$ \\
\hline$r^{e}$ & $\begin{array}{l}1.48 \\
{[6.17]}\end{array}$ & $\begin{array}{l}1.12 \\
{[4.64]}\end{array}$ & $\begin{array}{l}0.91 \\
{[4.31]}\end{array}$ & $\begin{array}{l}0.71 \\
{[3.70]}\end{array}$ & $\begin{array}{l}0.50 \\
{[2.39]}\end{array}$ & $\begin{array}{l}0.98 \\
{[6.44]}\end{array}$ \\
\hline$\alpha^{\mathrm{CAPM}}$ & $\begin{array}{l}0.83 \\
{[6.42]}\end{array}$ & $\begin{array}{l}0.42 \\
{[4.00]}\end{array}$ & $\begin{array}{l}0.28 \\
{[3.61]}\end{array}$ & $\begin{array}{l}0.12 \\
{[2.10]}\end{array}$ & $\begin{array}{l}-0.15 \\
{[-2.54]}\end{array}$ & $\begin{array}{l}0.97 \\
{[6.34]}\end{array}$ \\
\hline$\alpha^{\mathrm{FF} 3}$ & $\begin{array}{l}0.64 \\
{[6.32]}\end{array}$ & $\begin{array}{l}0.28 \\
{[3.06]}\end{array}$ & $\begin{array}{l}0.16 \\
{[2.22]}\end{array}$ & $\begin{array}{l}0.09 \\
{[1.58]}\end{array}$ & $\begin{array}{l}-0.03 \\
{[-0.56]}\end{array}$ & $\begin{array}{l}0.67 \\
{[5.76]}\end{array}$ \\
\hline$\alpha^{\mathrm{FF} 3+\mathrm{UMD}}$ & $\begin{array}{l}0.78 \\
{[7.95]}\end{array}$ & $\begin{array}{l}0.41 \\
{[4.60]}\end{array}$ & $\begin{array}{l}0.23 \\
{[3.34]}\end{array}$ & $\begin{array}{l}0.07 \\
{[1.26]}\end{array}$ & $\begin{array}{l}-0.04 \\
{[-0.72]}\end{array}$ & $\begin{array}{l}0.81 \\
{[7.22]}\end{array}$ \\
\hline$\alpha^{\mathrm{FF5}}$ & $\begin{array}{l}0.60 \\
{[5.79]}\end{array}$ & $\begin{array}{l}0.22 \\
{[2.39]}\end{array}$ & $\begin{array}{l}0.07 \\
{[0.97]}\end{array}$ & $\begin{array}{l}-0.01 \\
{[-0.25]}\end{array}$ & $\begin{array}{l}-0.03 \\
{[-0.68]}\end{array}$ & $\begin{array}{l}0.63 \\
{[5.35]}\end{array}$ \\
\hline \multicolumn{7}{|c|}{ Panel B: Quintile sort, equal-weighted, NYSE breaks } \\
\hline$r^{e}$ & $\begin{array}{l}1.61 \\
{[6.09]}\end{array}$ & $\begin{array}{l}1.02 \\
{[3.99]}\end{array}$ & $\begin{array}{l}0.82 \\
{[3.41]}\end{array}$ & $\begin{array}{l}0.69 \\
{[2.76]}\end{array}$ & $\begin{array}{l}0.41 \\
{[1.35]}\end{array}$ & $\begin{array}{l}1.20 \\
{[10.47]}\end{array}$ \\
\hline$\alpha^{\mathrm{CAPM}}$ & $\begin{array}{l}0.94 \\
{[5.79]}\end{array}$ & $\begin{array}{l}0.31 \\
{[2.41]}\end{array}$ & $\begin{array}{l}0.13 \\
{[1.19]}\end{array}$ & $\begin{array}{l}-0.04 \\
{[-0.40]}\end{array}$ & $\begin{array}{l}-0.42 \\
{[-2.57]}\end{array}$ & $\begin{array}{l}1.35 \\
{[12.85]}\end{array}$ \\
\hline$\alpha^{\mathrm{FF} 3}$ & $\begin{array}{l}0.66 \\
{[6.47]}\end{array}$ & $\begin{array}{l}0.07 \\
{[1.01]}\end{array}$ & $\begin{array}{l}-0.08 \\
{[-1.11]}\end{array}$ & $\begin{array}{l}-0.21 \\
{[-3.14]}\end{array}$ & $\begin{array}{l}-0.51 \\
{[-4.78]}\end{array}$ & $\begin{array}{l}1.18 \\
{[12.62]}\end{array}$ \\
\hline$\alpha^{\mathrm{FF} 3+\mathrm{UMD}}$ & $\begin{array}{l}0.85 \\
{[8.99]}\end{array}$ & $\begin{array}{l}0.22 \\
{[3.36]}\end{array}$ & $\begin{array}{l}0.06 \\
{[0.91]}\end{array}$ & $\begin{array}{l}-0.10 \\
{[-1.63]}\end{array}$ & $\begin{array}{l}-0.33 \\
{[-3.30]}\end{array}$ & $\begin{array}{l}1.19 \\
{[12.48]}\end{array}$ \\
\hline$\alpha^{\mathrm{FF5}}$ & $\begin{array}{l}0.73 \\
{[6.94]}\end{array}$ & $\begin{array}{l}0.11 \\
{[1.57]}\end{array}$ & $\begin{array}{l}-0.03 \\
{[-0.48]}\end{array}$ & $\begin{array}{l}-0.16 \\
{[-2.32]}\end{array}$ & $\begin{array}{l}-0.22 \\
{[-2.28]}\end{array}$ & $\begin{array}{l}0.95 \\
{[11.22]}\end{array}$ \\
\hline
\end{tabular}


Table B.1 (Continued): Robustness to Strategy Construction

\begin{tabular}{llllllllllll}
\hline \multicolumn{2}{c}{ Panel C: Decile sort, value-weighted, NYSE breaks } & & & & & & & & \\
& $(\mathrm{L})$ & $(2)$ & $(3)$ & $(4)$ & $(5)$ & $(6)$ & $(7)$ & $(8)$ & $(9)$ & $(\mathrm{H})$ & $(\mathrm{L}-\mathrm{H})$ \\
$r^{e}$ & 1.49 & 1.23 & 0.93 & 1.06 & 0.83 & 0.78 & 0.73 & 0.61 & 0.58 & 0.46 & 1.03 \\
& {$[6.13]$} & {$[5.00]$} & {$[3.95]$} & {$[4.93]$} & {$[4.13]$} & {$[4.03]$} & {$[3.62]$} & {$[2.96]$} & {$[2.89]$} & {$[2.04]$} & {$[6.50]$} \\
$\alpha^{\mathrm{CAPM}}$ & 0.83 & 0.53 & 0.25 & 0.43 & 0.24 & 0.22 & 0.13 & -0.01 & -0.02 & -0.22 & 1.05 \\
& {$[6.44]$} & {$[4.55]$} & {$[2.37]$} & {$[4.91]$} & {$[2.89]$} & {$[2.57]$} & {$[1.69]$} & {$[-0.08]$} & {$[-0.32]$} & {$[-2.79]$} & {$[6.55]$} \\
$\alpha^{\mathrm{FF} 3}$ & 0.63 & 0.37 & 0.11 & 0.30 & 0.14 & 0.14 & 0.07 & 0.02 & 0.05 & -0.08 & 0.71 \\
& {$[6.23]$} & {$[3.69]$} & {$[1.09]$} & {$[3.74]$} & {$[1.71]$} & {$[1.65]$} & {$[0.91]$} & {$[0.31]$} & {$[0.81]$} & {$[-1.24]$} & {$[5.62]$} \\
\multirow{2}{*}{$\alpha^{\mathrm{FF} 3+\mathrm{UMD}}$} & 0.76 & 0.51 & 0.23 & 0.34 & 0.19 & 0.13 & 0.05 & 0.00 & 0.05 & -0.10 & 0.87 \\
& {$[7.84]$} & {$[5.17]$} & {$[2.46]$} & {$[4.14]$} & {$[2.42]$} & {$[1.49]$} & {$[0.63]$} & {$[0.01]$} & {$[0.75]$} & {$[-1.49]$} & {$[7.01]$} \\
$\alpha^{\mathrm{FF5}}$ & 0.59 & 0.33 & 0.06 & 0.20 & 0.05 & 0.01 & -0.06 & -0.12 & -0.09 & -0.04 & 0.63 \\
& {$[5.75]$} & {$[3.18]$} & {$[0.62]$} & {$[2.37]$} & {$[0.66]$} & {$[0.12]$} & {$[-0.82]$} & {$[-1.54]$} & {$[-1.40]$} & {$[-0.51]$} & {$[4.86]$} \\
\hline \hline
\end{tabular}

$\pm$ 


\section{Appendix C Robustness to Underlying Characteristics}

In this section, we examine the cross-sectional return predictability of monetary policy exposure controlling for the characteristics used to construct the index. Table C.1 reports results from conditional double sorts on the characteristics and MPE. In each month, firms are first sorted into quintiles based on one of the five characteristics. Then, within each quintile, stocks are further sorted into quintiles based on their MPE, which leads to $5 \times 5$ portfolios, as in Table 7. As a final step, the firms in the resulting 5x5 portfolios are collapsed into five MPE-based portfolios by combining the firms in each characteristic decile for a given MPE quintile. The table reports average value-weighted excess returns to the resulting five MPE-based portfolios conditioned on each characteristic, as well as to a portfolio long stocks with low MPE and short stocks with high MPE. We observe that MPE preserves its predictive ability, controlling for the underlying characteristics. The lowest average monthly return on the long/short portfolios in the double sorts is achieved when conditioning on the Whited-Wu rank, but even in that case it amounts to 66 basis points, an estimate nearly five standard errors above zero.

Similarly, Table C.2 documents results from spanning tests, in which the returns to the long/short portfolio from Table 3 are regressed on a constant term and the returns to strategies constructed by quintile sorts on the underlying characteristics used to construct the monetary policy exposure measure. The results imply that the strategy based on monetary policy exposure is outside the span of the strategies based on the underlying characteristics, even when all of them are considered simultaneously. Specification (6) shows that the monetary policy exposure strategy has a significant alpha of 19 basis points per month ( $t$-statistic of 2.19) with respect to all of the underlying strategies.

Finally, Table C.3 reports results from estimating Fama-MacBeth regressions of firms' returns on monetary policy exposure and the underlying characteristics. Specifications (1)-(5) control for one of the characteristics at a time, while specifications (6)-(10) control for four of 
them at a time. We cannot control for all five of them simultaneously, because MPE is a linear combination of them. We observe that MPE has significant predictive power beyond that in the characteristics used to construct it. The lowest $t$-statistic (in absolute value) on MPE is in specification (8), which controls for Cash, CF Duration, CF Volatility, and Operating Profitability. Even in that specification, however, the estimated coefficient is over four standard errors below zero. 
Table C.1: Robustness to Underlying Characteristics: Double Sorts

This table reports average returns for double-sorted MPE portfolios. In each month, firms are sorted into quintiles based on one of the characteristics underlying the MPE index. Then, within each quintile, firms are further sorted into quintiles based on MPE. Firms are grouped into five MPE-based portfolios by combining the firms across the characteristic quintiles. The table reports value-weighted average excess returns for the five MPE portfolios and for a portfolio that is long stocks in the low MPE portfolio and short stocks in the high MPE portfolio. MPE is estimated using equation (3) from the text. The $t$-statistics are reported in brackets. The sample period is $01 / 1975$ to $12 / 2015$.

\begin{tabular}{|c|c|c|c|c|c|c|c|}
\hline \multirow{7}{*}{ 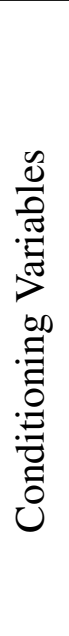 } & & \multicolumn{5}{|c|}{ MPE Quintiles } & \multirow[b]{2}{*}{$(\mathrm{L}-\mathrm{H})$} \\
\hline & & (L) & (2) & (3) & (4) & (H) & \\
\hline & Cash & $\begin{array}{l}1.31 \\
{[5.67]}\end{array}$ & $\begin{array}{l}1.09 \\
{[4.75]}\end{array}$ & $\begin{array}{l}0.84 \\
{[4.25]}\end{array}$ & $\begin{array}{l}0.69 \\
{[3.48]}\end{array}$ & $\begin{array}{l}0.53 \\
{[2.52]}\end{array}$ & $\begin{array}{l}0.78 \\
{[5.16]}\end{array}$ \\
\hline & CF Duration & $\begin{array}{l}1.47 \\
{[5.60]}\end{array}$ & $\begin{array}{l}1.11 \\
{[4.30]}\end{array}$ & $\begin{array}{l}0.86 \\
{[3.74]}\end{array}$ & $\begin{array}{l}0.64 \\
{[3.28]}\end{array}$ & $\begin{array}{l}0.53 \\
{[2.64]}\end{array}$ & $\begin{array}{l}0.94 \\
{[5.97]}\end{array}$ \\
\hline & Whited-Wu & $\begin{array}{l}1.12 \\
{[5.11]}\end{array}$ & $\begin{array}{l}0.93 \\
{[4.70]}\end{array}$ & $\begin{array}{l}0.75 \\
{[3.97]}\end{array}$ & $\begin{array}{l}0.58 \\
{[2.80]}\end{array}$ & $\begin{array}{l}0.47 \\
{[2.17]}\end{array}$ & $\begin{array}{l}0.66 \\
{[4.93]}\end{array}$ \\
\hline & CF Volatility & $\begin{array}{l}1.52 \\
{[6.09]}\end{array}$ & $\begin{array}{l}1.08 \\
{[4.31]}\end{array}$ & $\begin{array}{l}0.9 \\
{[3.98]}\end{array}$ & $\begin{array}{l}0.73 \\
{[3.76]}\end{array}$ & $\begin{array}{l}0.51 \\
{[2.54]}\end{array}$ & $\begin{array}{l}1.01 \\
{[6.60]}\end{array}$ \\
\hline & Op. Profit. & $\begin{array}{l}1.28 \\
{[5.07]}\end{array}$ & $\begin{array}{l}0.86 \\
{[4.23]}\end{array}$ & $\begin{array}{l}0.75 \\
{[3.63]}\end{array}$ & $\begin{array}{l}0.56 \\
{[2.60]}\end{array}$ & $\begin{array}{l}0.56 \\
{[2.81]}\end{array}$ & $\begin{array}{l}0.72 \\
{[4.75]}\end{array}$ \\
\hline
\end{tabular}


Table C.2: Robustness to Underlying Characteristics: Spanning Tests

The table documents results from time-series regressions of the returns to the strategy from Table 3 on returns to strategies constructed from the variables used to derive the monetary policy exposure (MPE). MPE is estimated using equation (3) from the text. All strategies are constructed on the same sample from a quintile sort using NYSE breakpoints. The $t$-statistics are in brackets. The sample period is $01 / 1975$ to $12 / 2015$.

\begin{tabular}{|c|c|c|c|c|c|c|}
\hline \multicolumn{7}{|c|}{ Regressions of the form $R_{t, M P E}=\alpha+\beta_{X} R_{X, t}+\varepsilon_{t}$} \\
\hline Coefficient & (1) & (2) & (3) & (4) & $(5)$ & (6) \\
\hline Const & $\begin{array}{l}0.69 \\
{[5.06]}\end{array}$ & $\begin{array}{l}0.71 \\
{[5.41]}\end{array}$ & $\begin{array}{l}0.71 \\
{[5.57]}\end{array}$ & $\begin{array}{l}0.79 \\
{[5.70]}\end{array}$ & $\begin{array}{l}0.52 \\
{[4.29]}\end{array}$ & $\begin{array}{l}0.19 \\
{[2.19]}\end{array}$ \\
\hline$\beta_{\text {Cash }}$ & $\begin{array}{l}17.28 \\
{[4.72]}\end{array}$ & & & & & $\begin{array}{l}26.00 \\
{[8.71]}\end{array}$ \\
\hline$\beta_{\mathrm{CF} \text { Duration }}$ & & $\begin{array}{l}-29.23 \\
{[-8.14]}\end{array}$ & & & & $\begin{array}{l}-31.19 \\
{[-10.86]}\end{array}$ \\
\hline$\beta_{\text {Whited Wu }}$ & & & $\begin{array}{l}25.00 \\
{[9.36]}\end{array}$ & & & $\begin{array}{l}36.15 \\
{[14.22]}\end{array}$ \\
\hline$\beta_{\mathrm{CF} \text { Volatility }}$ & & & & $\begin{array}{l}0.79 \\
{[0.20]}\end{array}$ & & $\begin{array}{l}-25.88 \\
{[-6.53]}\end{array}$ \\
\hline$\beta_{\text {Operating Profitability }}$ & & & & & $\begin{array}{l}51.86 \\
{[13.00]}\end{array}$ & $\begin{array}{l}47.16 \\
{[16.27]}\end{array}$ \\
\hline
\end{tabular}


Table C.3: Robustness to Underlying Characteristics: Fama-MacBeth Regressions

The table documents results from Fama-MacBeth regressions of the form $r_{t j}=\beta^{\prime} \mathbf{x}_{t-1, j}+\varepsilon_{t j}$. The characteristics $\mathbf{x}_{t-1, j}$ include monetary policy exposure and combinations of characteristics used to construct the monetary policy exposure index. MPE is estimated using equation (3) from the text. The $t$-statistics are in brackets. The sample period is $01 / 1975$ to $12 / 2015$.

\begin{tabular}{|c|c|c|c|c|c|c|c|c|c|c|}
\hline \multicolumn{11}{|c|}{ Regressions of the form $r_{t j}=\beta^{\prime} \mathbf{x}_{t-1, j}+\varepsilon_{t j}$} \\
\hline Coefficient & (1) & (2) & (3) & (4) & $(5)$ & (6) & (7) & (8) & (9) & (10) \\
\hline MPE & $\begin{array}{l}-30.95 \\
{[-9.89]}\end{array}$ & $\begin{array}{l}-37.60 \\
{[-13.02]}\end{array}$ & $\begin{array}{l}-33.11 \\
{[-10.77]}\end{array}$ & $\begin{array}{l}-38.35 \\
{[-11.26]}\end{array}$ & $\begin{array}{l}-27.88 \\
{[-10.96]}\end{array}$ & $\begin{array}{l}-52.46 \\
{[-12.52]}\end{array}$ & $\begin{array}{l}-27.83 \\
{[-4.48]}\end{array}$ & $\begin{array}{l}-36.01 \\
{[-4.01]}\end{array}$ & $\begin{array}{l}-28.58 \\
{[-9.53]}\end{array}$ & $\begin{array}{l}-58.82 \\
{[-12.45]}\end{array}$ \\
\hline Cash & $\begin{array}{l}0.93 \\
{[2.12]}\end{array}$ & & & & & & $\begin{array}{l}0.95 \\
{[2.12]}\end{array}$ & $\begin{array}{l}0.61 \\
{[1.51]}\end{array}$ & $\begin{array}{l}1.09 \\
{[3.31]}\end{array}$ & $\begin{array}{l}-0.35 \\
{[-1.00]}\end{array}$ \\
\hline CF Duration & & $\begin{array}{l}0.45 \\
{[1.64]}\end{array}$ & & & & $\begin{array}{l}0.81 \\
{[3.63]}\end{array}$ & & $\begin{array}{l}0.43 \\
{[1.45]}\end{array}$ & $\begin{array}{l}0.44 \\
{[2.62]}\end{array}$ & $\begin{array}{l}0.93 \\
{[4.71]}\end{array}$ \\
\hline Whited Wu & & & $\begin{array}{l}0.24 \\
{[0.68]}\end{array}$ & & & $\begin{array}{l}-0.61 \\
{[-2.06]}\end{array}$ & $\begin{array}{l}0.04 \\
{[0.10]}\end{array}$ & & $\begin{array}{l}-0.01 \\
{[-0.04]}\end{array}$ & $\begin{array}{l}-0.72 \\
{[-2.25]}\end{array}$ \\
\hline CF Volatility & & & & $\begin{array}{l}1.57 \\
{[2.29]}\end{array}$ & & $\begin{array}{l}2.70 \\
{[5.28]}\end{array}$ & $\begin{array}{l}0.93 \\
{[2.05]}\end{array}$ & $\begin{array}{l}1.22 \\
{[1.32]}\end{array}$ & & $\begin{array}{l}3.32 \\
{[7.07]}\end{array}$ \\
\hline Operating Profitability & & & & & $\begin{array}{l}2.51 \\
{[3.66]}\end{array}$ & $\begin{array}{l}0.45 \\
{[0.58]}\end{array}$ & $\begin{array}{l}2.82 \\
{[3.37]}\end{array}$ & $\begin{array}{l}1.94 \\
{[1.65]}\end{array}$ & $\begin{array}{l}2.90 \\
{[4.42]}\end{array}$ & \\
\hline
\end{tabular}




\section{Appendix D Robustness to Other Anomalies}

This section shows that the return predictability we document is not a different anomaly in disguise. To this end, Table D.1 reports average excess returns for conditional MPE strategies, constructed from double sorts on each of the 23 anomaly signals from Novy-Marx and Velikov (2016) and MPE. In each month, firms are sorted into quintiles based on one of the 23 anomaly signals. Then, within each quintile, stocks are further sorted into quintiles based on their MPE, which leads to $5 \times 5$ portfolios, as in Table 7. As a final step, the firms in the resulting $5 \times 5$ portfolios are collapsed into five MPE-based portfolios by combining the firms in each characteristic decile for a given MPE quintile. The table reports average value-weighted excess returns to the resulting five MPE-based portfolios conditioned on each signal, as well as to a portfolio long stocks with low MPE and short stocks with high MPE. We observe that the MPE strategies earn significantly positive returns on average, conditioning on any of the signals. The lowest average returns are earned by the MPE strategy constructed conditioning on the combined value and gross profitability signals (ValProf). However, even in that case, the MPE strategy earns an average return of 44 basis points with a $t$-statistic of 3.08 .

Table D.2 reports average excess returns and spanning tests between the strategy examined in Table 3 and the 23 anomalies from Novy-Marx and Velikov (2016). The spanning tests confirm the findings from Table D.1 and show that the MPE strategy has a positive and highly statistically significant information ratio relative to all of the 23 anomalies separately. Similar to the double sorts, the lowest alpha is achieved after controlling for the ValProf anomaly, but even in that case, as Panel B reports, it earns about half a percent per month, with a $t$-statistic of 3.98. Interestingly, as Panel $\mathrm{C}$ reports, the ValProf strategy has a significant loading on MPE, which results in an insignificant alpha of 0.20 percent per month ( $t$-statistic of 1.56), suggesting that the MPE-strategy subsumes the returns generated by ValProf strategy.

Finally, Table D.3 reports results from estimating Fama-MacBeth regressions of firms' re- 
turns on monetary policy exposure $(\times-1)$ and each of the anomaly characteristics individually. Again, we observe that MPE has a strong cross-sectional return predictive power that goes beyond what is contained in each of the 23 anomaly signals. 
Table D.1: Robustness to Other Anomalies: Double Sorts

The table reports average excess returns for conditional monetary policy exposure (MPE) strategies, constructed from double sorts on each of the 23 anomaly signals from Novy-Marx and Velikov (2016) and MPE. In each month, all firms in the CRSP/COMPUSTAT merged database are sorted into quintiles based on one of the 23 signals. Then, within each quintile, stocks are sorted into quintiles based on their MPE. Firms are grouped into five MPE-based portfolios by combining the firms across the characteristic quintiles. The table reports value-weighted average excess returns for the five MPE portfolios and for a portfolio that is long stocks in the low MPE portfolio and short stocks in the high MPE portfolio. The $t$-statistics are in brackets. The sample period is $01 / 1975$ to $12 / 2015$.

\begin{tabular}{|c|c|c|c|c|c|c|c|c|c|c|c|c|c|c|c|c|c|c|c|c|c|c|c|}
\hline 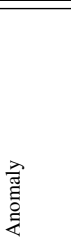 & $\stackrel{\mathscr{N}}{v^{2}}$ & 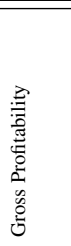 & 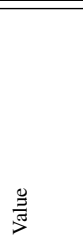 & 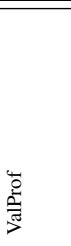 & $\begin{array}{l}\frac{n}{\tilde{J}} \\
\text { 莺 } \\
\text { 足 }\end{array}$ & 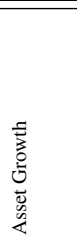 & 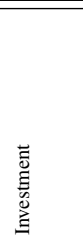 & 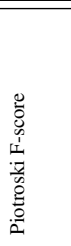 & 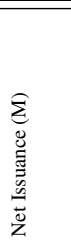 & 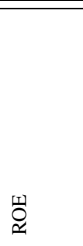 & 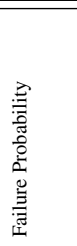 & 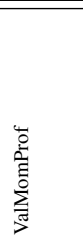 & 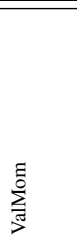 & 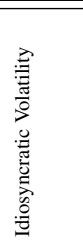 & 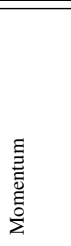 & 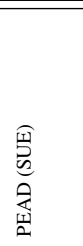 & 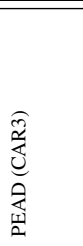 & 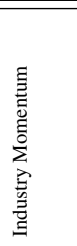 & 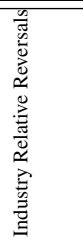 & 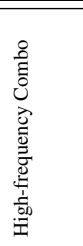 & 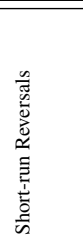 & 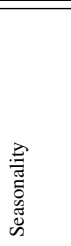 & 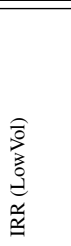 \\
\hline (L) & $\begin{array}{l}0.98 \\
{[4.46]}\end{array}$ & $\begin{array}{l}1.14 \\
{[4.80]}\end{array}$ & $\begin{array}{l}1.01 \\
{[4.05]}\end{array}$ & $\begin{array}{l}0.98 \\
{[3.89]}\end{array}$ & $\begin{array}{l}1.24 \\
{[5.07]}\end{array}$ & $\begin{array}{l}1.15 \\
{[4.66]}\end{array}$ & $\begin{array}{l}1.16 \\
{[4.77]}\end{array}$ & $\begin{array}{l}1.22 \\
{[5.01]}\end{array}$ & $\begin{array}{l}1.38 \\
{[5.52]}\end{array}$ & $\begin{array}{l}1.61 \\
{[6.83]}\end{array}$ & $\begin{array}{l}1.45 \\
{[6.17]}\end{array}$ & $\begin{array}{l}1.24 \\
{[4.63]}\end{array}$ & $\begin{array}{l}1.54 \\
{[6.29]}\end{array}$ & $\begin{array}{l}1.30 \\
{[6.00]}\end{array}$ & $\begin{array}{l}1.55 \\
{[6.68]}\end{array}$ & $\begin{array}{l}1.49 \\
{[6.27]}\end{array}$ & $\begin{array}{l}1.46 \\
{[6.16]}\end{array}$ & $\begin{array}{l}1.50 \\
{[6.36]}\end{array}$ & $\begin{array}{l}1.43 \\
{[6.01]}\end{array}$ & $\begin{array}{l}1.53 \\
{[6.36]}\end{array}$ & $\begin{array}{l}1.41 \\
{[5.87]}\end{array}$ & $\begin{array}{l}1.49 \\
{[6.35]}\end{array}$ & $\begin{array}{l}1.13 \\
{[5.20]}\end{array}$ \\
\hline (2) & $\begin{array}{l}0.80 \\
{[4.24]}\end{array}$ & $\begin{array}{l}0.88 \\
{[4.36]}\end{array}$ & $\begin{array}{l}0.87 \\
{[3.77]}\end{array}$ & $\begin{array}{l}0.83 \\
{[3.67]}\end{array}$ & $\begin{array}{l}0.94 \\
{[3.95]}\end{array}$ & $\begin{array}{l}0.92 \\
{[3.75]}\end{array}$ & $\begin{array}{l}0.89 \\
{[3.71]}\end{array}$ & $\begin{array}{l}0.99 \\
{[4.08]}\end{array}$ & $\begin{array}{l}1.01 \\
{[4.10]}\end{array}$ & $\begin{array}{l}1.18 \\
{[4.92]}\end{array}$ & $\begin{array}{l}1.04 \\
{[4.45]}\end{array}$ & $\begin{array}{l}0.95 \\
{[3.78]}\end{array}$ & $\begin{array}{l}1.09 \\
{[4.44]}\end{array}$ & $\begin{array}{l}0.99 \\
{[4.72]}\end{array}$ & $\begin{array}{l}1.08 \\
{[4.47]}\end{array}$ & $\begin{array}{l}1.13 \\
{[4.82]}\end{array}$ & $\begin{array}{l}1.07 \\
{[4.42]}\end{array}$ & $\begin{array}{l}1.00 \\
{[4.34]}\end{array}$ & $\begin{array}{l}1.06 \\
{[4.45]}\end{array}$ & $\begin{array}{l}1.07 \\
{[4.50]}\end{array}$ & $\begin{array}{l}1.07 \\
{[4.44]}\end{array}$ & $\begin{array}{l}1.11 \\
{[4.65]}\end{array}$ & $\begin{array}{l}0.91 \\
{[4.65]}\end{array}$ \\
\hline (3) & $\begin{array}{l}0.71 \\
{[3.52]}\end{array}$ & $\begin{array}{l}0.69 \\
{[3.51]}\end{array}$ & $\begin{array}{l}0.81 \\
{[3.83]}\end{array}$ & $\begin{array}{l}0.65 \\
{[3.26]}\end{array}$ & $\begin{array}{l}0.84 \\
{[4.02]}\end{array}$ & $\begin{array}{l}0.77 \\
{[3.47]}\end{array}$ & $\begin{array}{l}0.83 \\
{[3.89]}\end{array}$ & $\begin{array}{l}0.81 \\
{[3.78]}\end{array}$ & $\begin{array}{l}0.82 \\
{[3.88]}\end{array}$ & $\begin{array}{l}0.89 \\
{[4.23]}\end{array}$ & $\begin{array}{l}0.88 \\
{[4.31]}\end{array}$ & $\begin{array}{l}0.87 \\
{[3.91]}\end{array}$ & $\begin{array}{l}0.91 \\
{[4.24]}\end{array}$ & $\begin{array}{l}0.83 \\
{[4.31]}\end{array}$ & $\begin{array}{l}0.88 \\
{[4.18]}\end{array}$ & $\begin{array}{l}0.93 \\
{[4.52]}\end{array}$ & $\begin{array}{l}0.91 \\
{[4.42]}\end{array}$ & $\begin{array}{l}0.80 \\
{[3.99]}\end{array}$ & $\begin{array}{l}0.91 \\
{[4.42]}\end{array}$ & $\begin{array}{l}0.90 \\
{[4.40]}\end{array}$ & $\begin{array}{l}0.91 \\
{[4.41]}\end{array}$ & $\begin{array}{l}0.92 \\
{[4.54]}\end{array}$ & $\begin{array}{l}0.86 \\
{[4.71]}\end{array}$ \\
\hline (4) & $\begin{array}{l}0.50 \\
{[2.46]}\end{array}$ & $\begin{array}{l}0.61 \\
{[2.98]}\end{array}$ & $\begin{array}{l}0.53 \\
{[2.64]}\end{array}$ & $\begin{array}{l}0.56 \\
{[2.78]}\end{array}$ & $\begin{array}{l}0.66 \\
{[3.40]}\end{array}$ & $\begin{array}{l}0.61 \\
{[2.95]}\end{array}$ & $\begin{array}{l}0.58 \\
{[3.00]}\end{array}$ & $\begin{array}{l}0.65 \\
{[3.34]}\end{array}$ & $\begin{array}{l}0.69 \\
{[3.42]}\end{array}$ & $\begin{array}{l}0.66 \\
{[3.41]}\end{array}$ & $\begin{array}{l}0.66 \\
{[3.41]}\end{array}$ & $\begin{array}{l}0.60 \\
{[2.97]}\end{array}$ & $\begin{array}{l}0.64 \\
{[3.24]}\end{array}$ & $\begin{array}{l}0.62 \\
{[3.11]}\end{array}$ & $\begin{array}{l}0.67 \\
{[3.32]}\end{array}$ & $\begin{array}{l}0.69 \\
{[3.55]}\end{array}$ & $\begin{array}{l}0.67 \\
{[3.46]}\end{array}$ & $\begin{array}{l}0.67 \\
{[3.46]}\end{array}$ & $\begin{array}{l}0.66 \\
{[3.36]}\end{array}$ & $\begin{array}{l}0.66 \\
{[3.44]}\end{array}$ & $\begin{array}{l}0.67 \\
{[3.42]}\end{array}$ & {$\left[\begin{array}{l}0.67 \\
{[3.44]}\end{array}\right.$} & $\begin{array}{l}0.61 \\
{[3.34]}\end{array}$ \\
\hline (H) & $\begin{array}{l}0.42 \\
{[1.83]}\end{array}$ & $\begin{array}{l}0.55 \\
{[2.64]}\end{array}$ & $\begin{array}{l}0.43 \\
{[2.13]}\end{array}$ & $\begin{array}{l}0.54 \\
{[2.59]}\end{array}$ & $\begin{array}{l}0.49 \\
{[2.34]}\end{array}$ & $\begin{array}{l}0.51 \\
{[2.58]}\end{array}$ & $\begin{array}{l}0.51 \\
{[2.44]}\end{array}$ & $\begin{array}{l}0.49 \\
{[2.40]}\end{array}$ & $\begin{array}{l}0.52 \\
{[2.58]}\end{array}$ & $\begin{array}{l}0.50 \\
{[2.43]}\end{array}$ & $\begin{array}{l}0.51 \\
{[2.47]}\end{array}$ & $\begin{array}{l}0.55 \\
{[2.70]}\end{array}$ & $\begin{array}{l}0.54 \\
{[2.59]}\end{array}$ & $\begin{array}{l}0.53 \\
{[2.54]}\end{array}$ & $\begin{array}{l}0.54 \\
{[2.62]}\end{array}$ & $\begin{array}{l}0.49 \\
{[2.36]}\end{array}$ & $\begin{array}{l}0.52 \\
{[2.47]}\end{array}$ & $\begin{array}{l}0.53 \\
{[2.48]}\end{array}$ & $\begin{array}{l}0.51 \\
{[2.44]}\end{array}$ & $\begin{array}{l}0.51 \\
{[2.40]}\end{array}$ & $\begin{array}{l}0.51 \\
{[2.46]}\end{array}$ & $\begin{array}{l}0.51 \\
{[2.53]}\end{array}$ & $\begin{array}{l}0.65 \\
{[3.38]}\end{array}$ \\
\hline (L-H) & $\begin{array}{l}0.56 \\
{[3.96]}\end{array}$ & $\begin{array}{l}0.58 \\
{[3.98]}\end{array}$ & $\begin{array}{l}0.58 \\
{[4.24]}\end{array}$ & $\begin{array}{l}0.44 \\
{[3.08]}\end{array}$ & $\begin{array}{l}0.75 \\
{[4.85]}\end{array}$ & $\begin{array}{l}0.64 \\
{[4.37]}\end{array}$ & $\begin{array}{l}0.65 \\
{[4.33]}\end{array}$ & $\begin{array}{l}0.73 \\
{[4.67]}\end{array}$ & $\begin{array}{l}0.86 \\
{[5.69]}\end{array}$ & $\begin{array}{l}1.11 \\
{[7.61]}\end{array}$ & $\begin{array}{l}0.94 \\
{[6.51]}\end{array}$ & $\begin{array}{l}0.69 \\
{[3.92]}\end{array}$ & $\begin{array}{l}1.01 \\
{[6.37]}\end{array}$ & $\begin{array}{l}0.77 \\
{[5.87]}\end{array}$ & $\begin{array}{l}1.01 \\
{[7.08]}\end{array}$ & $\begin{array}{l}1.00 \\
{[6.71]}\end{array}$ & $\begin{array}{l}0.94 \\
{[6.30]}\end{array}$ & $\begin{array}{l}0.97 \\
{[6.76]}\end{array}$ & $\begin{array}{l}0.93 \\
{[6.25]}\end{array}$ & $\begin{array}{l}1.02 \\
{[6.80]}\end{array}$ & $\begin{array}{l}0.91 \\
{[5.99]}\end{array}$ & $\begin{array}{l}0.97 \\
{[6.40]}\end{array}$ & $\begin{array}{l}0.48 \\
{[3.50]}\end{array}$ \\
\hline
\end{tabular}


Table D.2: Robustness to Other Anomalies: Spanning Tests

The table reports average excess returns and spanning tests for the strategy examined in Table 3 and strategies that use one of the 23 signals from Novy-Marx and Velikov (2016). The strategies consist of long/short portfolios, constructed using quintile sorts with NYSE breakpoints. Panel A reports value-weighted average excess returns on the 23 strategies, Panel B reports spanning tests of the form $R_{t, i}=$ $\alpha+\beta R_{t, M P E}+\varepsilon_{t}$, and Panel C reports spanning tests of the form $R_{t, M P E}=\alpha+\beta R_{t, i}+\varepsilon_{t}$, where $R_{t, i}$ is one of the 23 anomaly strategies, and $R_{t, M P E}$ is the return on the strategy from Table 3. The $t$-statistics are in brackets. The sample period is 01/1975 to 12/2015.

\begin{tabular}{|c|c|c|c|c|c|c|c|c|c|c|c|c|c|c|c|c|c|c|c|c|c|c|c|}
\hline 苞 & $\stackrel{\sim}{2}$ & 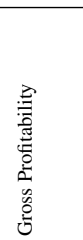 & $\frac{0}{\frac{\partial}{5}}$ & 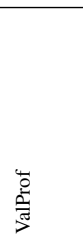 & 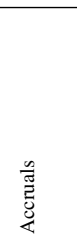 & 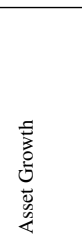 & 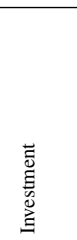 & 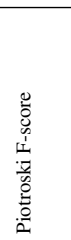 & 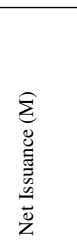 & $\stackrel{1100}{2}$ & 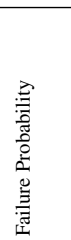 & 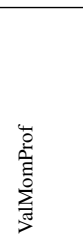 & $\sum_{j=}^{E}$ & 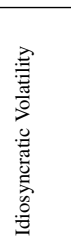 & 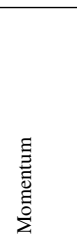 & 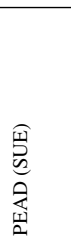 & 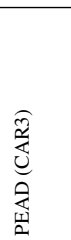 & 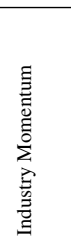 & 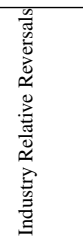 & 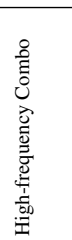 & 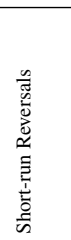 & 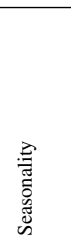 & 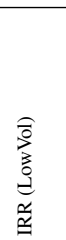 \\
\hline \multicolumn{24}{|c|}{ Panel A: Excess returns on 23 anomalies from Novy-Marx and Velikov 2016) } \\
\hline$r^{e}$ & $\begin{array}{l}0.25 \\
{[1.35]}\end{array}$ & $\begin{array}{l}0.28 \\
{[2.24]}\end{array}$ & $\begin{array}{l}0.34 \\
{[2.23]}\end{array}$ & $\begin{array}{l}0.70 \\
{[4.71]}\end{array}$ & $\begin{array}{l}0.10 \\
{[1.36]}\end{array}$ & $\begin{array}{l}0.20 \\
{[1.86]}\end{array}$ & $\begin{array}{l}0.32 \\
{[2.78]}\end{array}$ & $\begin{array}{l}0.31 \\
{[2.42]}\end{array}$ & $\begin{array}{l}0.36 \\
{[2.74]}\end{array}$ & $\begin{array}{l}0.46 \\
{[2.73]}\end{array}$ & $\begin{array}{l}0.34 \\
{[1.34]}\end{array}$ & $\begin{array}{l}0.93 \\
{[4.86]}\end{array}$ & $\begin{array}{l}0.59 \\
{[2.83]}\end{array}$ & $\begin{array}{l}0.22 \\
{[0.81]}\end{array}$ & $\begin{array}{l}0.74 \\
{[2.93]}\end{array}$ & $\begin{array}{l}0.35 \\
{[3.47]}\end{array}$ & $\begin{array}{l}0.50 \\
{[4.85]}\end{array}$ & $\begin{array}{l}0.63 \\
{[3.22]}\end{array}$ & $\begin{array}{l}0.75 \\
{[5.06]}\end{array}$ & $\begin{array}{l}0.92 \\
{[6.55]}\end{array}$ & $\begin{array}{l}0.35 \\
{[1.72]}\end{array}$ & $\begin{array}{l}0.56 \\
{[4.08]}\end{array}$ & $\begin{array}{l}1.04 \\
{[9.00]}\end{array}$ \\
\hline \multicolumn{24}{|c|}{ Panel B: Spanning tests of the form $R_{t, M P E}=\alpha+\beta R_{t, i}+\varepsilon_{t}$} \\
\hline$\alpha$ & $\begin{array}{l}0.74 \\
{[6.17]}\end{array}$ & $\begin{array}{l}0.90 \\
{[6.48]}\end{array}$ & $\begin{array}{l}0.69 \\
{[5.58]}\end{array}$ & $\begin{array}{l}0.48 \\
{[3.98]}\end{array}$ & $\begin{array}{l}0.84 \\
{[5.96]}\end{array}$ & $\begin{array}{l}0.76 \\
{[5.61]}\end{array}$ & $\begin{array}{l}0.78 \\
{[5.54]}\end{array}$ & $\begin{array}{l}0.88 \\
{[6.31]}\end{array}$ & $\begin{array}{l}0.85 \\
{[6.06]}\end{array}$ & $\begin{array}{l}0.98 \\
{[7.37]}\end{array}$ & $\begin{array}{l}0.92 \\
{[7.02]}\end{array}$ & $\begin{array}{l}0.82 \\
{[5.71]}\end{array}$ & $\begin{array}{l}0.96 \\
{[7.17]}\end{array}$ & $\begin{array}{l}0.87 \\
{[6.42]}\end{array}$ & $\begin{array}{l}0.95 \\
{[6.98]}\end{array}$ & $\begin{array}{l}0.86 \\
{[6.07]}\end{array}$ & $\begin{array}{l}0.93 \\
{[6.51]}\end{array}$ & $\begin{array}{l}0.87 \\
{[6.16]}\end{array}$ & $\begin{array}{l}0.69 \\
{[4.89]}\end{array}$ & $\begin{array}{l}0.81 \\
{[5.53]}\end{array}$ & $\begin{array}{l}0.79 \\
{[5.71]}\end{array}$ & $\begin{array}{l}0.94 \\
{[6.72]}\end{array}$ & $\begin{array}{l}0.66 \\
{[4.41]}\end{array}$ \\
\hline \multirow[t]{2}{*}{$\beta$} & 38.48 & - & 44.39 & 53.30 & -4.16 & 26.04 & 16.46 & - & -6.83 & & - & 1.03 & - & - & - & -8.57 & & -6.27 & 19.85 & 2.37 & 12.77 & - & 16.46 \\
\hline & [13.20] & $\begin{array}{l}22.54 \\
{[-.53]} \\
4.53] \\
\end{array}$ & [11.80] & [14.47] & $\begin{array}{l}{[-} \\
0.76] \\
\end{array}$ & [5.93] & [3.04] & $\begin{array}{l}16.60 \\
{[-} \\
3.35] \\
\end{array}$ & $\begin{array}{l}{[-} \\
1.41] \\
\end{array}$ & $\begin{array}{l}29.95 \\
{[-} \\
8.24]\end{array}$ & $\begin{array}{l}21.49 \\
{[-} \\
8.79] \\
\end{array}$ & [0.31] & $\begin{array}{l}21.48 \\
{[-} \\
7.36]\end{array}$ & $\begin{array}{l}14.21 \\
{[-} \\
6.37]\end{array}$ & $\begin{array}{l}15.68 \\
{[-} \\
6.44]\end{array}$ & $\begin{array}{l}{[-} \\
1.36]\end{array}$ & $\begin{array}{l}18.94 \\
{[-} \\
3.09]\end{array}$ & $\begin{array}{l}{[-} \\
1.95]\end{array}$ & [4.58] & {$[0.53]$} & [4.12] & $\begin{array}{l}20.46 \\
{[--} \\
4.43]\end{array}$ & [2.84] \\
\hline \multicolumn{24}{|c|}{ Panel C: Spanning tests of the form $R_{t, i}=\alpha+\beta R_{t, M P E}+\varepsilon_{t}$} \\
\hline$\alpha$ & $\begin{array}{l}-0.34 \\
{[--} \\
2.08]\end{array}$ & $\begin{array}{l}0.44 \\
{[3.49]}\end{array}$ & $\begin{array}{l}-0.11 \\
{[--} \\
0.79]\end{array}$ & $\begin{array}{l}0.20 \\
{[1.56]}\end{array}$ & $\begin{array}{l}0.20 \\
{[1.65]}\end{array}$ & $\begin{array}{l}0.04 \\
{[0.30]}\end{array}$ & $\begin{array}{l}0.23 \\
{[1.94]}\end{array}$ & $\begin{array}{l}0.42 \\
{[3.25]}\end{array}$ & $\begin{array}{l}0.42 \\
{[3.14]}\end{array}$ & $\begin{array}{l}0.83 \\
{[5.24]}\end{array}$ & $\begin{array}{l}0.94 \\
{[4.03]}\end{array}$ & $\begin{array}{l}0.92 \\
{[4.60]}\end{array}$ & $\begin{array}{l}1.00 \\
{[4.96]}\end{array}$ & $\begin{array}{l}0.71 \\
{[2.61]}\end{array}$ & $\begin{array}{l}1.18 \\
{[4.74]}\end{array}$ & $\begin{array}{l}0.41 \\
{[3.93]}\end{array}$ & $\begin{array}{l}0.60 \\
{[5.68]}\end{array}$ & $\begin{array}{l}0.74 \\
{[3.66]}\end{array}$ & $\begin{array}{l}0.54 \\
{[3.70]}\end{array}$ & $\begin{array}{l}0.89 \\
{[6.11]}\end{array}$ & $\begin{array}{l}0.09 \\
{[0.45]}\end{array}$ & $\begin{array}{l}0.69 \\
{[5.03]}\end{array}$ & $\begin{array}{l}0.92 \\
{[8.22]}\end{array}$ \\
\hline \multirow[t]{2}{*}{$\beta$} & $\begin{array}{l}2.001 \\
68.29\end{array}$ & - & 49.90 & 56.25 & -2.82 & 25.80 & 11.29 & - & -5.91 & - & - & 1.93 & - & - & - & -4.43 & - & - & 20.74 & 2.40 & 26.30 & - & 9.88 \\
\hline & [13.20] & $\begin{array}{l}17.85 \\
{[-} \\
4.53]\end{array}$ & {$[11.80]$} & {$[14.47]$} & $\begin{array}{l}{[-} \\
0.76]\end{array}$ & [5.93] & {$[3.04]$} & $\begin{array}{l}13.52 \\
{[-} \\
3.35]\end{array}$ & $\begin{array}{l}{[-} \\
1.41]\end{array}$ & $\begin{array}{l}40.72 \\
{[--72} \\
8.24]\end{array}$ & $\begin{array}{l}63.54 \\
{[--} \\
8.79]\end{array}$ & {$[0.31]$} & $\begin{array}{l}46.41 \\
{[--46]} \\
7.36]\end{array}$ & $\begin{array}{l}53.99 \\
{[-9} \\
6.37]\end{array}$ & $\begin{array}{l}49.89 \\
{[-} \\
6.44]\end{array}$ & $\begin{array}{l}{[-} \\
1.36]\end{array}$ & $\begin{array}{l}10.09 \\
{[-} \\
3.09]\end{array}$ & $\begin{array}{l}12.27 \\
{[-.95]} \\
1.95]\end{array}$ & {$[4.58]$} & {$[0.53]$} & {$[4.12]$} & $\begin{array}{l}18.85 \\
{[--} \\
4.43]\end{array}$ & [2.84] \\
\hline
\end{tabular}


Table D.3: Robustness to Other Anomalies: Fama-MacBeth Regressions

The table documents results from Fama-MacBeth regressions of the form $r_{t j}=\beta^{\prime} \mathbf{x}_{t-1, j}+\varepsilon_{t j}$. The characteristics $x_{t-1, j}$ include monetary policy exposure and anomaly signal characteristics from Novy-Marx and Velikov (2016). Monetary policy exposure is estimated using the coefficients on the interaction terms from Table 1. Panel A reports estimates from regressing returns on each of the 23 characteristics alone, while the regressions in Panel B also include MPE. The $t$-statistics are in brackets. The sample period is 01/1975 to 12/2015.

\begin{tabular}{|c|c|c|c|c|c|c|c|c|c|c|c|c|c|c|c|c|c|c|c|c|c|c|c|}
\hline 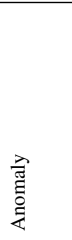 & $\stackrel{8}{2}$ & 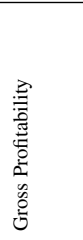 & 曾 & 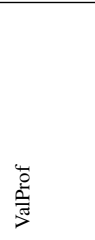 & 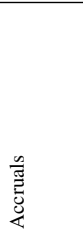 & 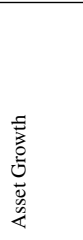 & 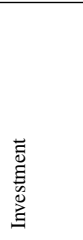 & 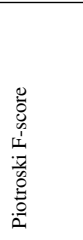 & 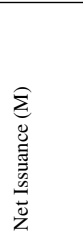 & $\begin{array}{l}\text { 뭉 } \\
\stackrel{2}{*}\end{array}$ & 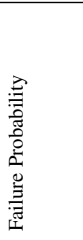 & 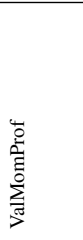 & 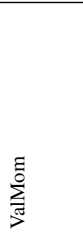 & 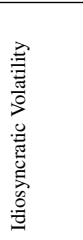 & 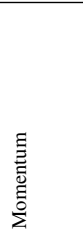 & 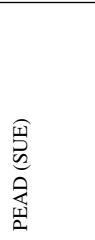 & 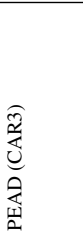 & 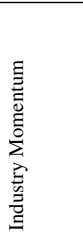 & 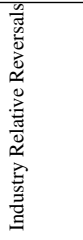 & 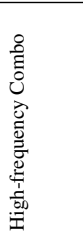 & 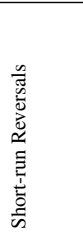 & 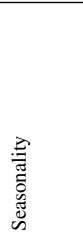 & 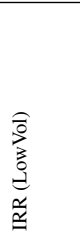 \\
\hline \multicolumn{24}{|c|}{ Panel A: Fama-MacBeth Regressions of the form $r_{t j}=a+b_{X} X_{t-1, j}+\varepsilon_{t j}$} \\
\hline$b_{X}$ & $\begin{array}{l}0.00 \\
{[2.73]}\end{array}$ & $\begin{array}{l}0.57 \\
{[4.81]}\end{array}$ & $\begin{array}{l}0.25 \\
{[6.29]}\end{array}$ & $\begin{array}{l}0.00 \\
{[7.12]}\end{array}$ & $\begin{array}{l}1.88 \\
{[5.79]}\end{array}$ & $\begin{array}{l}0.97 \\
{[8.32]}\end{array}$ & $\begin{array}{l}1.73 \\
{[10.16]}\end{array}$ & $\begin{array}{l}0.08 \\
{[2.35]}\end{array}$ & $\begin{array}{l}1.40 \\
{[4.20]}\end{array}$ & $\begin{array}{l}3.45 \\
{[3.80]}\end{array}$ & $\begin{array}{l}0.31 \\
{[3.85]}\end{array}$ & $\begin{array}{l}0.00 \\
{[10.46]}\end{array}$ & $\begin{array}{l}0.00 \\
{[6.98]}\end{array}$ & $\begin{array}{l}19.09 \\
{[3.71]}\end{array}$ & $\begin{array}{l}0.68 \\
{[2.97]}\end{array}$ & $\begin{array}{l}0.25 \\
{[14.70]}\end{array}$ & $\begin{array}{l}5.84 \\
{[18.51]}\end{array}$ & $\begin{array}{l}1.48 \\
{[10.40]}\end{array}$ & $\begin{array}{l}2.69 \\
{[15.38]}\end{array}$ & $\begin{array}{l}1.90 \\
{[22.79]}\end{array}$ & $\begin{array}{l}6.48 \\
{[14.51]}\end{array}$ & $\begin{array}{l}1.22 \\
{[7.23]}\end{array}$ & $\begin{array}{l}2.57 \\
{[17.00]}\end{array}$ \\
\hline \multicolumn{24}{|c|}{ Panel B: Fama-MacBeth Regressions of the form $r_{t j}=a+b_{X} \mathbf{X}_{t-1, j}+b_{\mathrm{MPE}}\left(-\mathrm{MPE}_{t-1, j}\right)+\varepsilon_{t j}$} \\
\hline$b_{X}$ & $\begin{array}{l}0.00 \\
{[1.70]}\end{array}$ & $\begin{array}{l}-0.02 \\
{[-} \\
0.12]\end{array}$ & $\begin{array}{l}0.00 \\
{[0.05]}\end{array}$ & $\begin{array}{l}0.00 \\
{[1.27]}\end{array}$ & $\begin{array}{l}1.87 \\
{[5.63]}\end{array}$ & $\begin{array}{l}0.77 \\
{[5.56]}\end{array}$ & $\begin{array}{l}1.19 \\
{[5.23]}\end{array}$ & $\begin{array}{l}0.02 \\
{[0.61]}\end{array}$ & $\begin{array}{l}0.97 \\
{[2.78]}\end{array}$ & $\begin{array}{l}2.59 \\
{[3.94]}\end{array}$ & $\begin{array}{l}0.23 \\
{[2.92]}\end{array}$ & $\begin{array}{l}0.00 \\
{[3.13]}\end{array}$ & $\begin{array}{l}0.00 \\
{[2.67]}\end{array}$ & $\begin{array}{l}8.60 \\
{[1.49]}\end{array}$ & $\begin{array}{l}0.49 \\
{[2.50]}\end{array}$ & $\begin{array}{l}0.25 \\
{[14.73]}\end{array}$ & $\begin{array}{l}5.36 \\
{[15.91]}\end{array}$ & $\begin{array}{l}1.38 \\
{[7.01]}\end{array}$ & $\begin{array}{l}2.37 \\
{[10.01]}\end{array}$ & $\begin{array}{l}1.67 \\
{[16.16]}\end{array}$ & $\begin{array}{l}4.64 \\
{[9.25]}\end{array}$ & $\begin{array}{l}0.94 \\
{[6.96]}\end{array}$ & $\begin{array}{l}2.10 \\
{[13.49]}\end{array}$ \\
\hline$b_{\mathrm{MPE}}$ & $\begin{array}{l}0.34 \\
{[12.80]}\end{array}$ & $\begin{array}{l}0.33 \\
{[12.54]}\end{array}$ & $\begin{array}{l}0.33 \\
{[13.79]}\end{array}$ & $\begin{array}{l}0.31 \\
{[12.67]}\end{array}$ & $\begin{array}{l}0.33 \\
{[12.80]}\end{array}$ & $\begin{array}{l}0.31 \\
{[12.25]}\end{array}$ & $\begin{array}{l}0.31 \\
{[12.34]}\end{array}$ & $\begin{array}{l}0.32 \\
{[12.61]}\end{array}$ & $\begin{array}{l}0.32 \\
{[12.92]}\end{array}$ & $\begin{array}{l}0.32 \\
{[12.64]}\end{array}$ & $\begin{array}{l}0.30 \\
{[11.39]}\end{array}$ & $\begin{array}{l}0.27 \\
{[8.56]}\end{array}$ & $\begin{array}{l}0.31 \\
{[11.54]}\end{array}$ & $\begin{array}{l}0.32 \\
{[12.55]}\end{array}$ & $\begin{array}{l}0.34 \\
{[14.28]}\end{array}$ & $\begin{array}{l}0.32 \\
{[12.30]}\end{array}$ & $\begin{array}{l}0.32 \\
{[12.65]}\end{array}$ & $\begin{array}{l}0.33 \\
{[13.09]}\end{array}$ & $\begin{array}{l}0.33 \\
{[13.11]}\end{array}$ & $\begin{array}{l}0.33 \\
{[13.11]}\end{array}$ & $\begin{array}{l}0.33 \\
{[13.28]}\end{array}$ & $\begin{array}{l}0.32 \\
{[12.38]}\end{array}$ & $\begin{array}{l}0.13 \\
{[4.66]}\end{array}$ \\
\hline
\end{tabular}




\section{Appendix E Robustness to the Reaction Window}

A potential concern regarding the monetary policy exposure measure we employ could arise from our choice of the number of days around FOMC meetings we use to gauge the firms' reactions. In our baseline estimations in Table 1 we use stocks' cumulative returns from the market close of the day prior to an FOMC meeting to the market close of the day following the FOMC meeting $\left(r_{0,1}\right)$. To ensure that our main results are not sensitive to this choice we examine three alternatives: from the market close of the day prior to the FOMC meeting to the market close of the day of the FOMC meeting $\left(r_{0,0}\right)$, and from the market close of the day prior to the FOMC meeting to the market close of the second and fifth day following the meeting $\left(r_{0,2}\right.$ and $r_{0,5}$, respectively).

Table E.1 replicates the tests from Table 3 using monetary policy exposure measures estimated using any of the three conventions for stocks' reaction around FOMC meetings $\left(r_{0,0}\right.$, $r_{0,2}$, and $\left.r_{0,5}\right)$. We observe that all of the other measures yield significant average returns and alphas with respect to all factor models. For example, using stocks' reaction on the day of the FOMC meetings $\left(r_{0,0}\right)$ produces an average return to the long/short portfolio of 58 basis points per month with a Fama and French (2015) five-factor alpha of 26 basis points $(t=4.35)$.

Given that scheduled FOMC meetings are highly anticipated events, it seems unlikely that it takes investors take more than two days to incorporate the information announced on the meeting day. Moreover, longer reaction windows incorporate policy-related news after the blackout period, thereby reducing the quality of the estimates of MPE. ${ }^{29}$ Thus, it is not surprising that using $r_{0,5}$ weakens the results. However, even with the noise introduced by going up to five days following the events, the long/short portfolio still generates a significant average monthly return of 0.41 percent per month ( $t$-statistic of 2.58) and highly significant alphas.

${ }^{29}$ In Greenspan's words about the post-FOMC blackout period, $\begin{array}{r}\text { "the } \\ \text { thrust of the announced decision of the Committee then } \\ \text { (https://www.federalreserve.gov/monetarypolicy/files/FOMC19950201meeting.pdf) }\end{array}$


Similarly, Table E.2 reports estimates from Fama-MacBeth cross-sectional regressions of returns on monetary policy exposure, estimated using the three conventions and other controls. We observe that, regardless of the method used to estimate monetary policy exposure, it seems to be a robust predictor of returns in the cross-section. The predictability of monetary policy exposure survives even after controlling for common predictors of returns, such as size, value, profitability, momentum, and last month's return. 
Table E.1: Robustness to Measuring the Reaction: Portfolio Sorts

This table reports average excess returns and alphas for portfolios constructed by sorting on different monetary policy exposure (MPE) indices. In each month, firms are sorted by their monetary policy exposure into quintiles based on NYSE breakpoints. Average value-weighted returns in excess of the risk-free rate and alphas with respect to the CAPM, the Fama and French (1993) three-factor model, the Fama and French (1993) three-factor model augmented with the Carhart (1997) momentum factor, and the Fama and French (2015) five-factor model are reported for each of the five portfolios and for a portfolio long stocks with low MPE and short stocks with high MPE. In Panel A, monetary policy exposure is estimated using stocks' daily return on the FOMC meetings in Equation (2). In Panel B, monetary policy exposure is estimated using stocks' three-day return (days zero, one, and two) around the FOMC meetings in Equation (2). In Panel C, monetary policy exposure is estimated using stocks' six-day return (days zero, one, two, three, four, and five) around the FOMC meetings in Equation (2). The $t$-statistics are in brackets. The sample period is $01 / 1975$ to $12 / 2015$.

\begin{tabular}{|c|c|c|c|c|c|c|}
\hline \multicolumn{7}{|c|}{ Panel A: MPE $=\mathrm{MPE}_{r_{0,0}}$} \\
\hline & $(\mathrm{L})$ & (2) & (3) & (4) & $(\mathrm{H})$ & $(\mathrm{L}-\mathrm{H})$ \\
\hline$r^{e}$ & $\begin{array}{l}1.12 \\
{[4.13]}\end{array}$ & $\begin{array}{l}0.86 \\
{[3.60]}\end{array}$ & $\begin{array}{l}0.82 \\
{[3.91]}\end{array}$ & $\begin{array}{l}0.80 \\
{[3.99]}\end{array}$ & $\begin{array}{l}0.53 \\
{[2.66]}\end{array}$ & $\begin{array}{l}0.58 \\
{[3.51]}\end{array}$ \\
\hline$\alpha^{\mathrm{CAPM}}$ & $\begin{array}{l}0.37 \\
{[2.69]}\end{array}$ & $\begin{array}{l}0.15 \\
{[1.64]}\end{array}$ & $\begin{array}{l}0.19 \\
{[2.56]}\end{array}$ & $\begin{array}{l}0.19 \\
{[2.98]}\end{array}$ & $\begin{array}{l}-0.09 \\
{[-1.78]}\end{array}$ & $\begin{array}{l}0.46 \\
{[2.79]}\end{array}$ \\
\hline$\alpha^{\mathrm{FF} 3}$ & $\begin{array}{l}0.20 \\
{[4.14]}\end{array}$ & $\begin{array}{l}0.02 \\
{[0.31]}\end{array}$ & $\begin{array}{l}0.08 \\
{[1.22]}\end{array}$ & $\begin{array}{l}0.12 \\
{[1.99]}\end{array}$ & $\begin{array}{l}0.03 \\
{[0.73]}\end{array}$ & $\begin{array}{l}0.17 \\
{[2.63]}\end{array}$ \\
\hline$\alpha^{\mathrm{FF} 3+\mathrm{UMD}}$ & $\begin{array}{l}0.22 \\
{[4.61]}\end{array}$ & $\begin{array}{l}0.06 \\
{[1.11]}\end{array}$ & $\begin{array}{l}0.13 \\
{[1.83]}\end{array}$ & $\begin{array}{l}0.11 \\
{[1.69]}\end{array}$ & $\begin{array}{l}0.02 \\
{[0.62]}\end{array}$ & $\begin{array}{l}0.20 \\
{[3.04]}\end{array}$ \\
\hline$\alpha^{\mathrm{FF} 5}$ & $\begin{array}{l}0.24 \\
{[5.28]}\end{array}$ & $\begin{array}{l}0.02 \\
{[0.41]}\end{array}$ & $\begin{array}{l}0.10 \\
{[1.43]}\end{array}$ & $\begin{array}{l}0.05 \\
{[0.82]}\end{array}$ & $\begin{array}{l}-0.02 \\
{[-0.60]}\end{array}$ & $\begin{array}{l}0.26 \\
{[4.35]}\end{array}$ \\
\hline \multicolumn{7}{|c|}{ Panel B: $\mathrm{MPE}=\mathrm{MPE}_{r_{0,2}}$} \\
\hline$r^{e}$ & $\begin{array}{l}1.12 \\
{[4.99]}\end{array}$ & $\begin{array}{l}0.98 \\
{[5.18]}\end{array}$ & $\begin{array}{l}0.68 \\
{[3.54]}\end{array}$ & $\begin{array}{l}0.63 \\
{[3.08]}\end{array}$ & $\begin{array}{l}0.49 \\
{[2.17]}\end{array}$ & $\begin{array}{l}0.63 \\
{[4.33]}\end{array}$ \\
\hline$\alpha^{\mathrm{CAPM}}$ & $\begin{array}{l}0.49 \\
{[4.52]}\end{array}$ & $\begin{array}{l}0.43 \\
{[5.28]}\end{array}$ & $\begin{array}{l}0.11 \\
{[1.48]}\end{array}$ & $\begin{array}{l}0.01 \\
{[0.12]}\end{array}$ & $\begin{array}{l}-0.20 \\
{[-2.97]}\end{array}$ & $\begin{array}{l}0.69 \\
{[4.69]}\end{array}$ \\
\hline$\alpha^{\mathrm{FF} 3}$ & $\begin{array}{l}0.28 \\
{[3.05]}\end{array}$ & $\begin{array}{l}0.30 \\
{[4.24]}\end{array}$ & $\begin{array}{l}0.03 \\
{[0.38]}\end{array}$ & $\begin{array}{l}0.05 \\
{[0.78]}\end{array}$ & $\begin{array}{l}-0.06 \\
{[-1.12]}\end{array}$ & $\begin{array}{l}0.34 \\
{[2.99]}\end{array}$ \\
\hline$\alpha^{\mathrm{FF} 3+\mathrm{UMD}}$ & $\begin{array}{l}0.42 \\
{[4.79]}\end{array}$ & $\begin{array}{l}0.33 \\
{[4.67]}\end{array}$ & $\begin{array}{l}0.04 \\
{[0.58]}\end{array}$ & $\begin{array}{l}0.04 \\
{[0.58]}\end{array}$ & $\begin{array}{l}-0.08 \\
{[-1.52]}\end{array}$ & $\begin{array}{l}0.50 \\
{[4.58]}\end{array}$ \\
\hline$\alpha^{\mathrm{FF5}}$ & $\begin{array}{l}0.23 \\
{[2.41]}\end{array}$ & $\begin{array}{l}0.18 \\
{[2.50]}\end{array}$ & $\begin{array}{l}-0.11 \\
{[-1.59]}\end{array}$ & $\begin{array}{l}-0.12 \\
{[-2.00]}\end{array}$ & $\begin{array}{l}-0.07 \\
{[-1.32]}\end{array}$ & $\begin{array}{l}0.30 \\
{[2.54]}\end{array}$ \\
\hline
\end{tabular}


Table E.1 (Continued): Robustness to Measuring the Reaction: Portfolio Sorts

\begin{tabular}{|c|c|c|c|c|c|c|}
\hline \multicolumn{7}{|c|}{ Panel C: MPE $=$ MPE $_{r_{0,5}}$} \\
\hline & (L) & (2) & (3) & (4) & $(\mathrm{H})$ & $(\mathrm{L}-\mathrm{H})$ \\
\hline$r^{e}$ & $\begin{array}{l}0.95 \\
{[4.82]}\end{array}$ & $\begin{array}{l}0.85 \\
{[4.49]}\end{array}$ & $\begin{array}{l}0.66 \\
{[3.36]}\end{array}$ & $\begin{array}{l}0.62 \\
{[3.08]}\end{array}$ & $\begin{array}{l}0.53 \\
{[2.19]}\end{array}$ & $\begin{array}{l}0.41 \\
{[2.58]}\end{array}$ \\
\hline$\alpha^{\mathrm{CAPM}}$ & $\begin{array}{l}0.40 \\
{[4.04]}\end{array}$ & $\begin{array}{l}0.31 \\
{[3.55]}\end{array}$ & $\begin{array}{l}0.08 \\
{[1.03]}\end{array}$ & $\begin{array}{l}0.01 \\
{[0.17]}\end{array}$ & $\begin{array}{l}-0.21 \\
{[-2.64]}\end{array}$ & $\begin{array}{l}0.61 \\
{[4.03]}\end{array}$ \\
\hline$\alpha^{\mathrm{FF} 3}$ & $\begin{array}{l}0.20 \\
{[2.41]}\end{array}$ & $\begin{array}{l}0.17 \\
{[2.32]}\end{array}$ & $\begin{array}{l}0.03 \\
{[0.41]}\end{array}$ & $\begin{array}{l}0.07 \\
{[1.02]}\end{array}$ & $\begin{array}{l}-0.05 \\
{[-0.95]}\end{array}$ & $\begin{array}{l}0.25 \\
{[2.41]}\end{array}$ \\
\hline$\alpha^{\mathrm{FF} 3+\mathrm{UMD}}$ & $\begin{array}{l}0.27 \\
{[3.37]}\end{array}$ & $\begin{array}{l}0.17 \\
{[2.29]}\end{array}$ & $\begin{array}{l}0.05 \\
{[0.61]}\end{array}$ & $\begin{array}{l}0.04 \\
{[0.57]}\end{array}$ & $\begin{array}{l}-0.05 \\
{[-0.90]}\end{array}$ & $\begin{array}{l}0.32 \\
{[3.11]}\end{array}$ \\
\hline$\alpha^{\mathrm{FF} 5}$ & $\begin{array}{l}0.16 \\
{[1.92]}\end{array}$ & $\begin{array}{l}0.01 \\
{[0.16]}\end{array}$ & $\begin{array}{l}-0.16 \\
{[-2.35]}\end{array}$ & $\begin{array}{l}-0.16 \\
{[-2.69]}\end{array}$ & $\begin{array}{l}0.00 \\
{[0.00]}\end{array}$ & $\begin{array}{l}0.16 \\
{[1.50]}\end{array}$ \\
\hline
\end{tabular}


Table E.2: Robustness to Measuring the Reaction: Fama-MacBeth Regressions

This table documents results from Fama-MacBeth regressions of the form $r_{t j}=\beta^{\prime} \mathbf{x}_{t-1, j}+\varepsilon_{t j}$. The characteristics $\mathbf{x}_{t-1, j}$ include the three monetary policy exposure (MPE) indices from Table E.1, the $\log$ of market capitalization $(\log (\mathrm{ME})$ ), the $\log$ of the book-to-market ratio $(\log (\mathrm{BM}))$, gross profitability (GP/A), investment (I/A), momentum $\left(r_{12,1}\right)$, and short-term reversals $\left(r_{1,0}\right)$. MPE is estimated using equation (3) from the text. GP/A follows Novy-Marx (2013). I/A follows Cooper, Gulen, and Schill (2008). Independent variables are winsorized at the 1 percent level. The $t$-statistics are in brackets. The sample period is $01 / 1975$ to 12/2015.

\begin{tabular}{|c|c|c|c|c|c|c|c|}
\hline \multicolumn{8}{|c|}{ Regressions of the form $r_{t j}=\beta^{\prime} \mathbf{x}_{t-1, j}+\varepsilon_{t j}$} \\
\hline Coef. & $(1)$ & $(2)$ & (3) & (4) & $(5)$ & (6) & (7) \\
\hline $\mathrm{MPE}_{y=r_{0,0}}$ & $\begin{array}{l}-30.00 \\
{[-6.35]}\end{array}$ & & & & $\begin{array}{l}-13.93 \\
{[-3.28]}\end{array}$ & & \\
\hline $\mathrm{MPE}_{y=r_{0,2}}$ & & $\begin{array}{l}-29.23 \\
{[-9.63]}\end{array}$ & & & & $\begin{array}{l}-29.33 \\
{[-10.24]}\end{array}$ & \\
\hline $\mathrm{MPE}_{y=r_{0,5}}$ & & & $\begin{array}{l}-10.84 \\
{[-5.62]}\end{array}$ & & & & $\begin{array}{l}-10.80 \\
{[-6.43]}\end{array}$ \\
\hline $\log (\mathrm{ME})$ & & & & $\begin{array}{l}-0.12 \\
{[-2.73]}\end{array}$ & $\begin{array}{l}-0.06 \\
{[-1.15]}\end{array}$ & $\begin{array}{l}-0.12 \\
{[-2.71]}\end{array}$ & $\begin{array}{l}-0.16 \\
{[-3.96]}\end{array}$ \\
\hline $\log (\mathrm{B} / \mathrm{M})$ & & & & $\begin{array}{l}0.25 \\
{[3.75]}\end{array}$ & $\begin{array}{l}0.19 \\
{[2.83]}\end{array}$ & $\begin{array}{l}-0.13 \\
{[-2.17]}\end{array}$ & $\begin{array}{l}-0.08 \\
{[-1.39]}\end{array}$ \\
\hline GP/A & & & & $\begin{array}{l}0.65 \\
{[4.53]}\end{array}$ & $\begin{array}{l}0.54 \\
{[3.82]}\end{array}$ & $\begin{array}{l}-0.14 \\
{[-1.04]}\end{array}$ & $\begin{array}{l}0.17 \\
{[1.25]}\end{array}$ \\
\hline $\mathrm{I} / \mathrm{A}$ & & & & $\begin{array}{l}-0.77 \\
{[-9.30]}\end{array}$ & $\begin{array}{l}-0.69 \\
{[-7.39]}\end{array}$ & $\begin{array}{l}-0.64 \\
{[-6.88]}\end{array}$ & $\begin{array}{l}-0.66 \\
{[-7.18]}\end{array}$ \\
\hline$r_{12,1}$ & & & & $\begin{array}{l}0.32 \\
{[1.79]}\end{array}$ & $\begin{array}{l}0.41 \\
{[2.40]}\end{array}$ & $\begin{array}{l}0.50 \\
{[2.84]}\end{array}$ & $\begin{array}{l}0.49 \\
{[2.77]}\end{array}$ \\
\hline$r_{1,0}$ & & & & $\begin{array}{l}-5.37 \\
{[-12.63]}\end{array}$ & $\begin{array}{l}-5.34 \\
{[-12.86]}\end{array}$ & $\begin{array}{l}-5.35 \\
{[-12.78]}\end{array}$ & $\begin{array}{l}-5.34 \\
{[-12.82]}\end{array}$ \\
\hline
\end{tabular}




\section{Appendix F Robustness to the Event Window of Surprise}

Another potential concern regarding the monetary policy exposure measure we employ could arise from the event window of monetary policy surprises. In our baseline estimations in Table 1. we use the Gürkaynak, Sack, and Swanson (2005) "tight" measure ( $\left.\Delta i_{\mathrm{GSS}, \text { tight }}^{u}\right)$, but in this section we demonstrate that our results are robust to using their "wide" measure $\Delta i_{\mathrm{GSS}}^{u}$, wide, as well as the surprise component of announcements from the Bernanke and Kuttner (2005) measure $\left(\Delta i_{\mathrm{BK}}^{u}\right)$.

For an FOMC meeting happening on day $d$ of month $m$, with the public announcement at 2:15 pm, the surprise changes in the federal funds rate are given by:

$$
\begin{aligned}
\Delta i_{\mathrm{BK}}^{u} & =\frac{D}{D-d}\left(f_{m, d, \text { Close }}^{0}-f_{m, d-1, \text { Close }}^{0}\right) \\
\Delta i_{\mathrm{GSS}, \text { tight }}^{u} & =\frac{D}{D-d}\left(f_{m, d, \text { Post } 2: 35 \mathrm{pm}}^{0}-f_{m, d, \text { Pre } 2: 05 \mathrm{pm}}^{0}\right) \\
\Delta i_{\mathrm{GSS}, \text { wide }}^{u} & =\frac{D}{D-d}\left(f_{m, d, \text { Post } 3: 00 \mathrm{pm}}^{0}-f_{m, d, \text { Pre } 2: 00 \mathrm{pm}}^{0}\right),
\end{aligned}
$$

where $D$ is the number of days in the month, $f_{m, d, \text { Close }}^{0}$ is the federal funds rate implied by the closing price on day $d$ of the federal funds futures contract expiring in the current month, $f_{m, d, \text { Post } 2: 35 \mathrm{pm}}^{0}$ is the federal funds rate implied by the first trade after 2:35 pm on day $d$ of the federal funds futures contract expiring in the current month, $f_{m, d, \text { Pre 2:05 pm }}^{0}$ is the federal funds rate implied by the last trade before $2: 05 \mathrm{pm}$ on day $d$ of the federal funds futures contract expiring in the current month, and $f_{m, d-1, \text { Close }}^{0}, f_{m, d, \text { Post 3:00 pm }}^{0}$ and $f_{m, d, \text { Pre 2:00 pm }}^{0}$ are defined analogously. For those cases where the scheduled announcements is not at 2:15 pm, the 30and 60-minutes event window is shifted accordingly.

All three measures equal a difference between federal funds rates before and after the announcement implied by prices of the federal funds futures contracts expiring in the current month. The Bernanke and Kuttner (2005) measure uses daily changes, while the Gürkaynak, 
Sack, and Swanson (2005) measures use intraday changes. The three measures are highly correlated. For the 115 meetings used in this study, the Bernanke and Kuttner (2005) surprises have a 91.12 percent and 92.36 percent correlation with the Gürkaynak, Sack, and Swanson (2005) "tight" and "wide" surprises, respectively, while the two intraday surprise measures have a correlation of 99.20 percent. Following Bernanke and Kuttner (2005), our identification of monetary policy exposure comes from regressing the returns around the scheduled FOMC announcement on the surprise component of policy rate change on that announcement date. The resulting MPE measures from the three surprises are given by:

$$
\begin{aligned}
& \mathrm{MPE}_{\mathrm{BK}}=-3.13 \times \text { Cash }+1.43 \times \mathrm{CF} \text { Duration Rank }-2.11 \times \text { Whited-Wu Rank } \\
&+8.66 \times \mathrm{CF} \text { Volatility }-9.06 \times \text { Operating Profitability } \\
& \mathrm{MPE}_{\mathrm{GSS}, \text { tight }}=-4.99 \times \mathrm{Cash}+1.75 \times \mathrm{CF} \text { Duration Rank }-2.10 \times \text { Whited-Wu Rank } \\
&+9.26 \times \mathrm{CF} \text { Volatility }-11.84 \times \text { Operating Profitability }, \\
& \mathrm{MPE}_{\mathrm{GSS}, \text { wide }}=-4.76 \times \mathrm{Cash}+1.60 \times \mathrm{CF} \text { Duration Rank }-1.40 \times \text { Whited-Wu Rank } \\
&+8.10 \times \mathrm{CF} \text { Volatility }-11.42 \times \text { Operating Profitability } .
\end{aligned}
$$

We observe that the estimated coefficients are close to each other, which indicates the stability of the relationship between monetary policy exposure and the variables we have chosen to construct the index. The main asset pricing results from the paper, replicated using $\mathrm{MPE}_{\mathrm{BK}}$ and $\mathrm{MPE}_{\mathrm{GSS}}$, wide, are reported in Table F.1. We observe that in both cases, the strategies continue to generate returns and alphas that are highly significant in both statistical and economical terms. 
Similarly, Table F.2 reports estimates from Fama-MacBeth cross-sectional regressions of returns on monetary policy exposure, estimated using the two surprise measures and other controls. We observe that, regardless of the surprise used to estimate monetary policy exposure, it seems to be a robust predictor of returns in the cross-section. The predictability of monetary policy exposure survives even after controlling for common predictors of returns, such as size, value, profitability, momentum, and last month's return. 
Table F.1: Robustness to Different Monetary Policy Surprises: Portfolio Sorts

This table reports average excess returns and alphas for portfolios constructed by sorting on different monetary policy exposure (MPE) indices. In each month, firms are sorted by their monetary policy exposure into quintiles based on NYSE breakpoints. Average value-weighted returns in excess of the risk-free rate and alphas with respect to the CAPM, the Fama and French (1993) three-factor model, the Fama and French (1993) three-factor model augmented with the Carhart (1997) momentum factor, and the Fama and French (2015) five-factor model are reported for each of the five portfolios and for a portfolio long stocks with low MPE and short stocks with high MPE. In Panel A, monetary policy exposure is estimated using the federal funds rate surprises from Bernanke and Kuttner (2005) in Equation (2). In Panel B, monetary policy exposure is estimated using the "wide" federal funds rate surprises from Gürkaynak, Sack, and Swanson (2005) in Equation (2). The $t$-statistics are in brackets. The sample period is $01 / 1975$ to $12 / 2015$.

\begin{tabular}{|c|c|c|c|c|c|c|}
\hline \multicolumn{7}{|c|}{ Panel A: $\mathrm{MPE}=\mathrm{MPE}_{\mathrm{BK}}$} \\
\hline & $(\mathrm{L})$ & (2) & (3) & (4) & $(\mathrm{H})$ & $(\mathrm{L}-\mathrm{H})$ \\
\hline$r^{e}$ & $\begin{array}{l}1.31 \\
{[5.48]}\end{array}$ & $\begin{array}{l}0.95 \\
{[4.29]}\end{array}$ & $\begin{array}{l}0.81 \\
{[4.17]}\end{array}$ & $\begin{array}{l}0.67 \\
{[3.43]}\end{array}$ & $\begin{array}{l}0.52 \\
{[2.49]}\end{array}$ & $\begin{array}{l}0.79 \\
{[5.67]}\end{array}$ \\
\hline$\alpha^{\mathrm{CAPM}}$ & $\begin{array}{l}0.63 \\
{[5.56]}\end{array}$ & $\begin{array}{l}0.29 \\
{[3.40]}\end{array}$ & $\begin{array}{l}0.24 \\
{[3.13]}\end{array}$ & $\begin{array}{l}0.08 \\
{[1.21]}\end{array}$ & $\begin{array}{l}-0.13 \\
{[-2.28]}\end{array}$ & $\begin{array}{l}0.76 \\
{[5.42]}\end{array}$ \\
\hline$\alpha^{\mathrm{FF} 3}$ & $\begin{array}{l}0.44 \\
{[5.18]}\end{array}$ & $\begin{array}{l}0.15 \\
{[1.95]}\end{array}$ & $\begin{array}{l}0.13 \\
{[1.87]}\end{array}$ & $\begin{array}{l}0.07 \\
{[1.08]}\end{array}$ & $\begin{array}{l}-0.01 \\
{[-0.17]}\end{array}$ & $\begin{array}{l}0.45 \\
{[4.52]}\end{array}$ \\
\hline$\alpha^{\mathrm{FF} 3+\mathrm{UMD}}$ & $\begin{array}{l}0.57 \\
{[6.88]}\end{array}$ & $\begin{array}{l}0.23 \\
{[3.06]}\end{array}$ & $\begin{array}{l}0.14 \\
{[2.08]}\end{array}$ & $\begin{array}{l}0.04 \\
{[0.65]}\end{array}$ & $\begin{array}{l}-0.01 \\
{[-0.23]}\end{array}$ & $\begin{array}{l}0.58 \\
{[5.92]}\end{array}$ \\
\hline$\alpha^{\mathrm{FF} 5}$ & $\begin{array}{l}0.40 \\
{[4.58]}\end{array}$ & $\begin{array}{l}0.09 \\
{[1.12]}\end{array}$ & $\begin{array}{l}0.03 \\
{[0.47]}\end{array}$ & $\begin{array}{l}-0.06 \\
{[-1.03]}\end{array}$ & $\begin{array}{l}-0.03 \\
{[-0.64]}\end{array}$ & $\begin{array}{l}0.43 \\
{[4.20]}\end{array}$ \\
\hline \multicolumn{7}{|c|}{ Panel B: MPE $=\mathrm{MPE}_{\mathrm{GSS}}$, wide } \\
\hline$r^{e}$ & $\begin{array}{l}1.27 \\
{[5.37]}\end{array}$ & $\begin{array}{l}1.03 \\
{[4.91]}\end{array}$ & $\begin{array}{l}0.76 \\
{[3.96]}\end{array}$ & $\begin{array}{l}0.64 \\
{[3.20]}\end{array}$ & $\begin{array}{l}0.47 \\
{[2.22]}\end{array}$ & $\begin{array}{l}0.79 \\
{[5.84]}\end{array}$ \\
\hline$\alpha^{\mathrm{CAPM}}$ & $\begin{array}{l}0.59 \\
{[5.50]}\end{array}$ & $\begin{array}{l}0.41 \\
{[4.95]}\end{array}$ & $\begin{array}{l}0.19 \\
{[2.57]}\end{array}$ & $\begin{array}{l}0.03 \\
{[0.47]}\end{array}$ & $\begin{array}{l}-0.18 \\
{[-3.07]}\end{array}$ & $\begin{array}{l}0.77 \\
{[5.66]}\end{array}$ \\
\hline$\alpha^{\mathrm{FF} 3}$ & $\begin{array}{l}0.43 \\
{[4.72]}\end{array}$ & $\begin{array}{l}0.28 \\
{[3.69]}\end{array}$ & $\begin{array}{l}0.10 \\
{[1.41]}\end{array}$ & $\begin{array}{l}0.04 \\
{[0.70]}\end{array}$ & $\begin{array}{l}-0.06 \\
{[-1.23]}\end{array}$ & $\begin{array}{l}0.49 \\
{[4.45]}\end{array}$ \\
\hline$\alpha^{\mathrm{FF} 3+\mathrm{UMD}}$ & $\begin{array}{l}0.57 \\
{[6.57]}\end{array}$ & $\begin{array}{l}0.35 \\
{[4.66]}\end{array}$ & $\begin{array}{l}0.10 \\
{[1.51]}\end{array}$ & $\begin{array}{l}0.02 \\
{[0.37]}\end{array}$ & $\begin{array}{l}-0.07 \\
{[-1.47]}\end{array}$ & $\begin{array}{l}0.64 \\
{[6.05]}\end{array}$ \\
\hline$\alpha^{\mathrm{FF} 5}$ & $\begin{array}{l}0.37 \\
{[3.99]}\end{array}$ & $\begin{array}{l}0.19 \\
{[2.48]}\end{array}$ & $\begin{array}{l}-0.04 \\
{[-0.55]}\end{array}$ & $\begin{array}{l}-0.09 \\
{[-1.39]}\end{array}$ & $\begin{array}{l}-0.08 \\
{[-1.63]}\end{array}$ & $\begin{array}{l}0.45 \\
{[3.99]}\end{array}$ \\
\hline
\end{tabular}


Table F.2: Robustness to Different Monetary Policy Surprises: Fama-MacBeth Regressions This table documents results from Fama-MacBeth regressions of the form $r_{t j}=\beta^{\prime} \mathbf{x}_{t-1, j}+\varepsilon_{t j}$. The characteristics $\mathbf{x}_{t-1, j}$ include the two monetary policy exposure (MPE) indices from Table F.1, the $\log$ of market capitalization $(\log (\mathrm{ME}))$, the $\log$ of the book-to-market ratio $(\log (\mathrm{BM}))$, gross profitability (GP/A), investment (I/A), momentum $\left(r_{12,1}\right)$, and short-term reversals $\left(r_{1,0}\right)$. GP/A follows Novy-Marx (2013). I/A follows Cooper, Gulen, and Schill (2008). Independent variables are winsorized at the 1 percent level. The $t$-statistics are in brackets. The sample period is $01 / 1975$ to $12 / 2015$.

\begin{tabular}{|c|c|c|c|c|c|}
\hline \multirow{3}{*}{$\begin{array}{l}\text { Coef. } \\
\text { MPE }_{\mathrm{BK}}\end{array}$} & \multicolumn{5}{|c|}{ Regressions of the form $r_{t j}=\beta^{\prime} \mathbf{x}_{t j}+\varepsilon_{t j}$} \\
\hline & (1) & (2) & (3) & (4) & (5) \\
\hline & $\begin{array}{l}-36.60 \\
{[-11.65]}\end{array}$ & & & $\begin{array}{l}-30.96 \\
{[-9.63]}\end{array}$ & \\
\hline $\mathrm{MPE}_{\mathrm{GSS} \text {,wide }}$ & & $\begin{array}{l}-38.18 \\
{[-12.98]}\end{array}$ & & & $\begin{array}{l}-35.54 \\
{[-12.29]}\end{array}$ \\
\hline $\log (\mathrm{ME})$ & & & $\begin{array}{l}-0.12 \\
{[-2.73]}\end{array}$ & $\begin{array}{l}-0.05 \\
{[-1.12]}\end{array}$ & $\begin{array}{l}-0.07 \\
{[-1.46]}\end{array}$ \\
\hline $\log (\mathrm{B} / \mathrm{M})$ & & & $\begin{array}{l}0.25 \\
{[3.75]}\end{array}$ & $\begin{array}{l}0.03 \\
{[0.45]}\end{array}$ & $\begin{array}{l}-0.05 \\
{[-0.77]}\end{array}$ \\
\hline GP/A & & & $\begin{array}{l}0.65 \\
{[4.53]}\end{array}$ & $\begin{array}{l}0.08 \\
{[0.61]}\end{array}$ & $\begin{array}{l}-0.10 \\
{[-0.69]}\end{array}$ \\
\hline I/A & & & $\begin{array}{l}-0.77 \\
{[-9.30]}\end{array}$ & $\begin{array}{l}-0.62 \\
{[-6.63]}\end{array}$ & $\begin{array}{l}-0.61 \\
{[-6.53]}\end{array}$ \\
\hline$r_{12,1}$ & & & $\begin{array}{l}0.32 \\
{[1.79]}\end{array}$ & $\begin{array}{l}0.43 \\
{[2.46]}\end{array}$ & $\begin{array}{l}0.47 \\
{[2.67]}\end{array}$ \\
\hline$r_{1,0}$ & & & $\begin{array}{l}-5.37 \\
{[-12.63]}\end{array}$ & $\begin{array}{l}-5.37 \\
{[-12.84]}\end{array}$ & $\begin{array}{l}-5.35 \\
{[-12.75]}\end{array}$ \\
\hline
\end{tabular}

